\title{
Production and Emissions of Marine Isoprene and Monoterpenes: A Review
}

\author{
Stephanie L. Shaw, ${ }^{1}$ Brett Gantt, ${ }^{2}$ and Nicholas Meskhidze ${ }^{2}$ \\ ${ }^{1}$ Electric Power Research Institute, Palo Alto, CA 94304, USA \\ ${ }^{2}$ North Carolina State University, Raleigh, NC 27695, USA \\ Correspondence should be addressed to Stephanie L. Shaw, slshaw@alum.mit.edu
}

Received 14 March 2010; Revised 17 June 2010; Accepted 5 August 2010

Academic Editor: Olaf Stetzer

Copyright (C) 2010 Stephanie L. Shaw et al. This is an open access article distributed under the Creative Commons Attribution License, which permits unrestricted use, distribution, and reproduction in any medium, provided the original work is properly cited.

Terrestrial and marine photosynthetic organisms emit trace gases, including isoprene and monoterpenes. The resulting emissions can impact the atmosphere through oxidative chemistry and formation of secondary organic aerosol. Large uncertainty exists as to the magnitude of the marine sources of these compounds, their controlling factors, and contribution to marine aerosol. In recent years, the number of relevant studies has increased substantially, necessitating the review of this topic. Isoprene emissions vary with plankton species, chlorophyll concentration, light, and other factors. Remote marine boundary layer isoprene mixing ratios can reach $>300 \mathrm{pptv}$, and extrapolated global ocean fluxes range from $<1$ to $>10 \mathrm{Tg} \mathrm{C}$ year ${ }^{-1}$. Modeling studies using surface chlorophyll concentration as an isoprene emissions proxy suggest variable atmospheric impacts. More information is needed, including emission fluxes of isoprene and monoterpenes from various biogeographical areas, the effects of species and nutrient limitation on emissions, and the aerosol yields via condensation and nucleation, in order to better quantify the atmospheric impacts of marine isoprene and monoterpenes.

\section{Introduction}

It is has been well established that photosynthetic organisms can emit trace gases, collectively known as biogenic volatile organic compounds (BVOCs), that play a role in the formation of ozone $\left(\mathrm{O}_{3}\right)$ and help extend the lifetime of important atmospheric gases such as methane and carbon monoxide. Isoprene $\left(\mathrm{C}_{5} \mathrm{H}_{8}\right)$ is the atmosphere's most ubiquitous BVOC with annual global emissions estimated at $500-750 \mathrm{Tg}$ of carbon [1]. While terrestrial vegetation has the highest isoprene emission rates, it has been shown that productive areas of remote ocean, coastal upwelling regions, and wetlands [2-4] can all emit isoprene at rates that can potentially influence the oxidation capacity of the atmosphere in remote marine and coastal regions [5-9]. In addition to its photochemical role, isoprene has been shown to be an important precursor to secondary organic aerosol (SOA) formation $[10,11]$. Recent studies revealed that SOA can strongly impact the radiation balance of the atmosphere, modify cloud microphysics, and participate in chemical transformations. Marine SOA of biogenic origin could be especially important for understanding the cloud-mediated effects of aerosols on climate, because cloud properties respond to aerosols in a nonlinear way and are most sensitive to the addition of particles when the background concentration is low [12]. While the role of ocean ecology in shaping the microphysical properties of low-level marine clouds and planetary albedo is highly uncertain, it has been found that organic aerosol emitted over biologically active oceanic regions can potentially influence number concentration and chemical composition of accumulation mode marine aerosols [13-18]. The incomplete characterization of these impacts in remote marine regions is seen as a major obstacle for improved understanding of radiative balance, contributing up to $80 \%$ uncertainty in simulated values of aerosol indirect effect [19].

While it is clear that heterotrophic bacteria, marine phytoplankton, and seaweeds can all emit isoprene [2, 2022 ], current debate centers on (1) the magnitude and spatial distribution of global marine fluxes of isoprene, 
(2) sensitivities of marine isoprene emissions to environmental parameters (e.g., incoming solar radiation, temperature, and nutrient abundance), (3) dependence of marine isoprene emissions on phytoplankton speciation, (4) contribution of marine isoprene-derived SOA to submicron marine aerosol mass, (5) relative amounts of marine isoprene-derived SOA to SOA formed from other marine BVOCs, (6) the role of marine isoprene-derived organic vapors on potential enhancement of nucleation events and growth of ultrafine particles in coastal and remote ocean environments, and (7) the nature of marine monoterpene emissions, which were only very recently discovered in both laboratory and field work. Finally, due to its ubiquitous production by photosynthetic vegetation, marine isoprene can also be used as a tracer of ocean biological processes when continental influence is eliminated.

In order to better quantify the roles of marine isoprene and monoterpenes in atmospheric chemistry and climate, the spatial distribution of the production and emission mechanisms need to be better constrained. This paper will review the state of the science of marine isoprene and monoterpene research through 2009 ( $\sim 70$ publications including articles in press and recent conference results) and give recommendations for improvement of present marine emission parameterizations. Three general types of studies are described: laboratory measurements on monocultures or simple mixtures of phytoplankton and other organisms, field measurements (including transects and mesocosm studies), and global estimates by modeling approaches. Each of these has their own benefits and drawbacks. For example, laboratory studies can better elucidate processes/mechanisms, and more closely approximate cause-and-effect experiments. Field studies can directly measure emission fluxes, integrate various simultaneously-acting source and sink mechanisms on chemical concentration, and are not subject to bottle effects. As all three types of studies provide information on production or emission rates of isoprene and monoterpenes, all are included and distinguished when relevant. When necessary some production rates or fluxes were converted between various units or estimated based on information provided in the publications.

\section{Marine Isoprene Seawater Concentrations}

The first report of marine isoprene, and observed correlations between seawater isoprene and chlorophyll concentration, was in the field measurements of Bonsang et al. [2]. In depth profiles from various Pacific Ocean and Mediterranean Sea sites, it was observed that the isoprene concentration maxima were broadly consistent with chlorophyll concentration maxima (based on chlorophyll fluorescence). Other field studies [24-26] also found subsurface isoprene concentration maxima at depth broadly coinciding with chlorophyll in the Florida Straits, eastern Atlantic Ocean, and Northeast Pacific sites. It should be noted that throughout the paper we will refer to both chlorophyll and chlorophyll-a as "chlorophyll" when authors do not make clear distinction of specific pigment composition. When specified, "chlorophylla" or "Chl-a" will be used.
Surface seawater measurements conducted in the North Sea and the Southern Ocean showed positive correlations of isoprene and chlorophyll that were independent of the presence of individual phytoplankton species [3]. These authors observed a seasonal isoprene concentration cycle of two orders of magnitude, with isoprene consistently supersaturated in seawater relative to its ambient concentrations. These commonly observed positive correlations of isoprene and chlorophyll imply a direct biogenic source of isoprene from phytoplankton. Published observations of isoprene concentrations in seawater are listed in Table 1 and depicted in Figure 1.

Field enclosures and mesoscale enrichment experiments in surface ocean waters populated by phytoplankton have clearly shown rapid isoprene production responses after changes in ambient conditions. For example, Wingenter et al. [23] observed 3-to 7-fold increases in isoprene concentrations in air equilibrated with seawater inside an ironfertilized patch during the Southern Ocean Iron Experiment (SOFEX) experiment. These concentrations were positively correlated with biological productivity (which coincided with a shift in plankton species present), suggesting that phytoplankton community growth and speciation shifts are also important controls on isoprene emissions. Based on these results, the authors hypothesized that the glacial era iron fertilization may have impacted the atmosphere through release of isoprene and other biogenic trace gases. A separate iron fertilization experiment in the North Pacific [24] exhibited 6-fold higher isoprene production rates inside the fertilized patch as compared to outside of the patch. A mesocosm study in a Norwegian fjord [39] showed that air concentrations of isoprene peaked from $12-4 \mathrm{pm}$, the portion of day with highest typical light and temperate intensity, and were at minimum levels at night. Interestingly, some isoprene emission occurred in overcast skies and at night, which the authors hypothesize was likely due to ventilation of built up mixed layer concentrations produced during daylight hours.

\section{Marine Isoprene Production Rates}

3.1. Laboratory Studies of Environmental and Physiological Controls. In addition to ambient measurements, isoprene production has also been detected from more than 27 phytoplankton species grown in the laboratory by a number of researchers under varying conditions. The results summarized in Table 2 (and Figure 2) exhibit a large variation in production rates ranging over several orders of magnitude.

Shaw et al. [21] tested the effects of a variety of physiological parameters and microorganism interactions on isoprene production rates by phytoplankton monocultures. They showed that isoprene production by phytoplankton exhibited maxima at certain light $\left(>150 \mu \mathrm{E} / \mathrm{m}^{2} / \mathrm{sec}\right)$ and temperature conditions $\left(23^{\circ} \mathrm{C}\right)$. A rapid increase in isoprene production was observed at low light levels, with a gradual increase as irradiance increased, until production rates leveled off. This pattern of isoprene production was shown to be similar to that of terrestrial vegetation (e.g., [43]). A comparison by Gantt et al. [22] of chlorophyll-normalized 


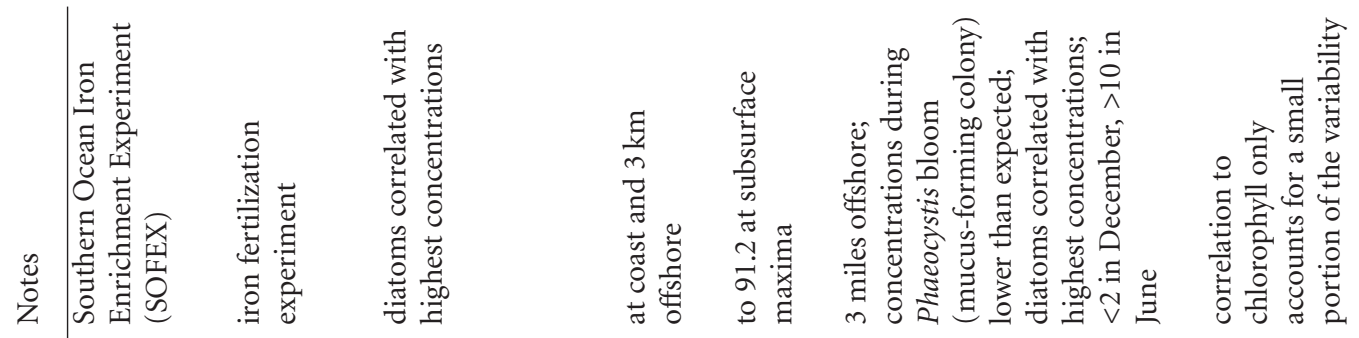

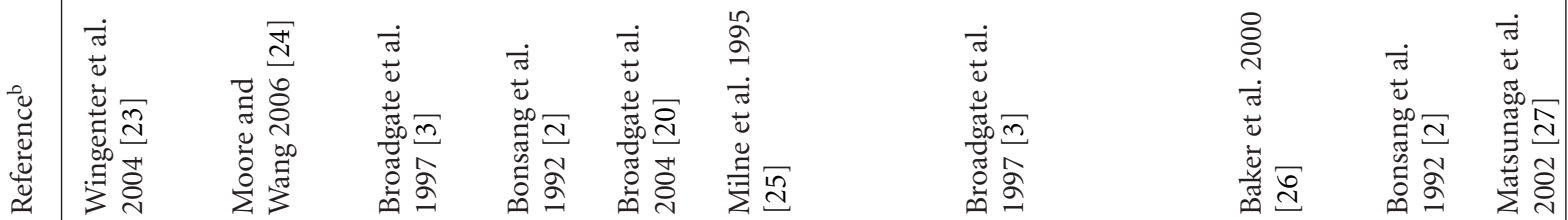

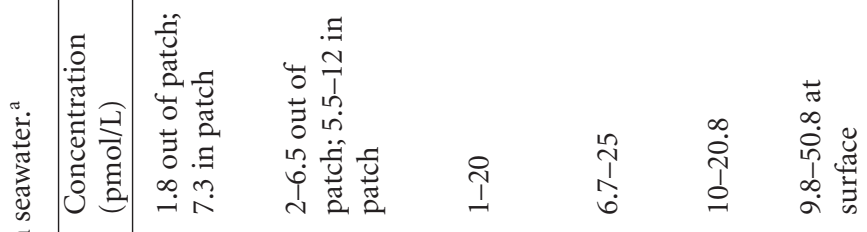

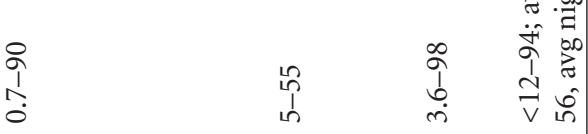

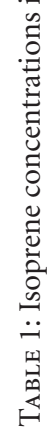

(2)

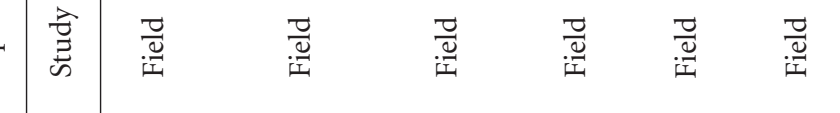

물

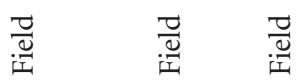

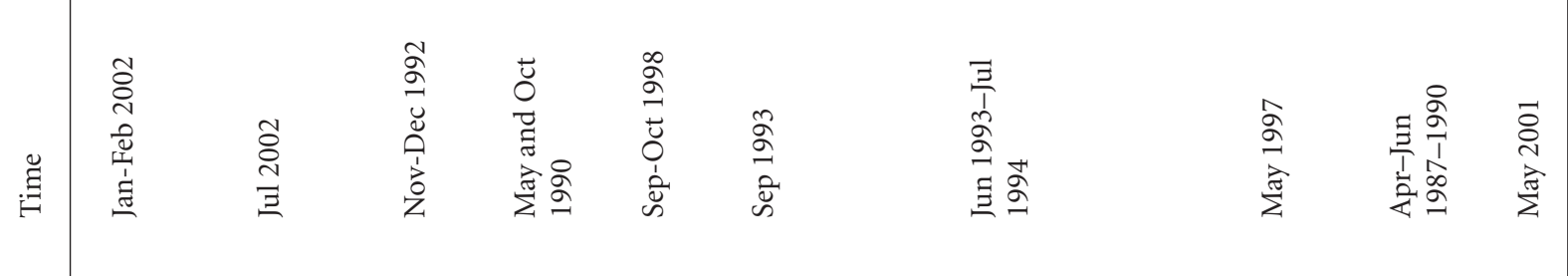

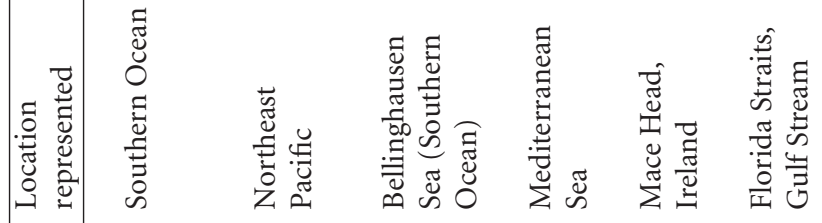

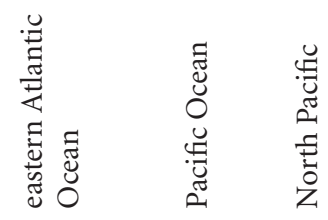




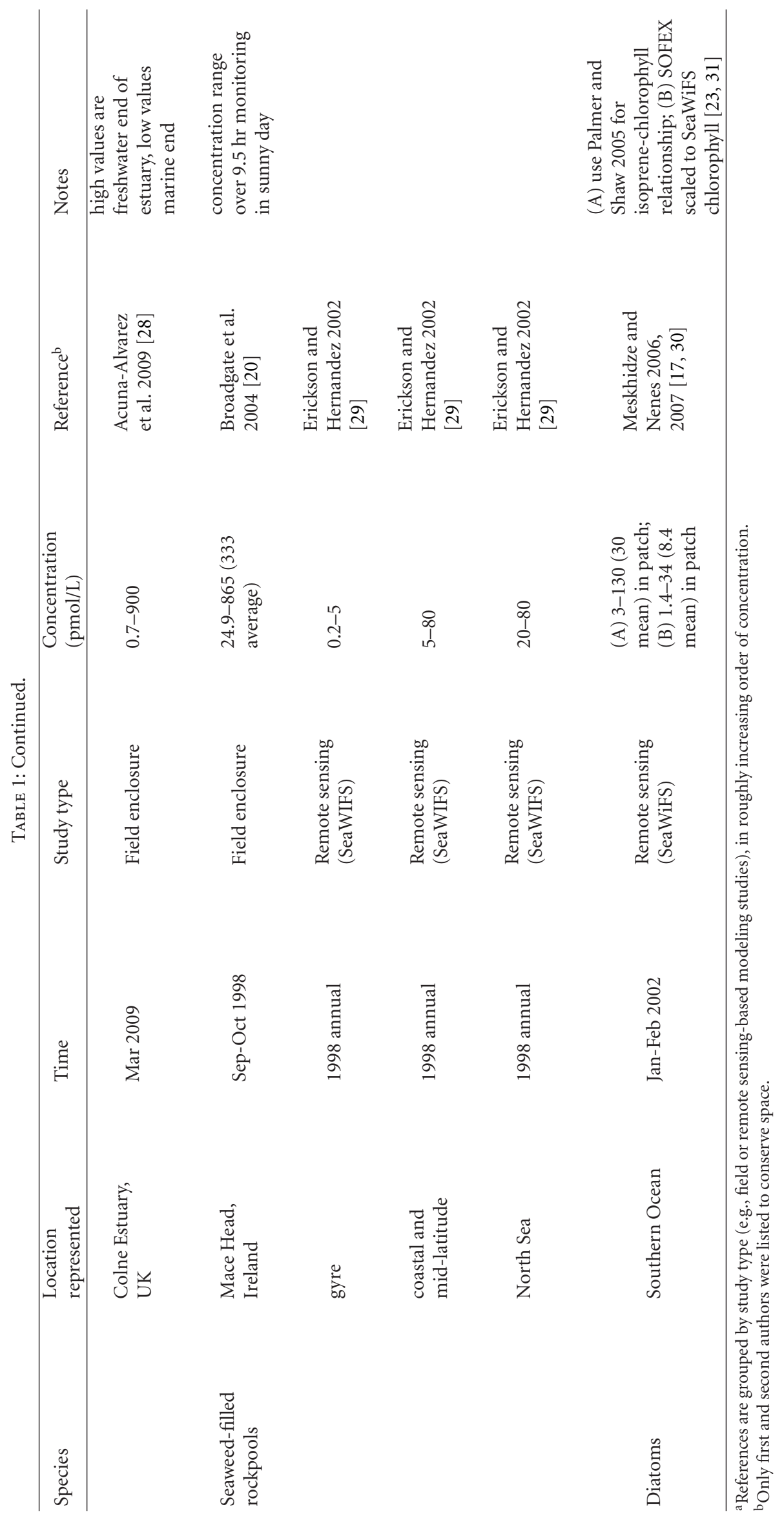




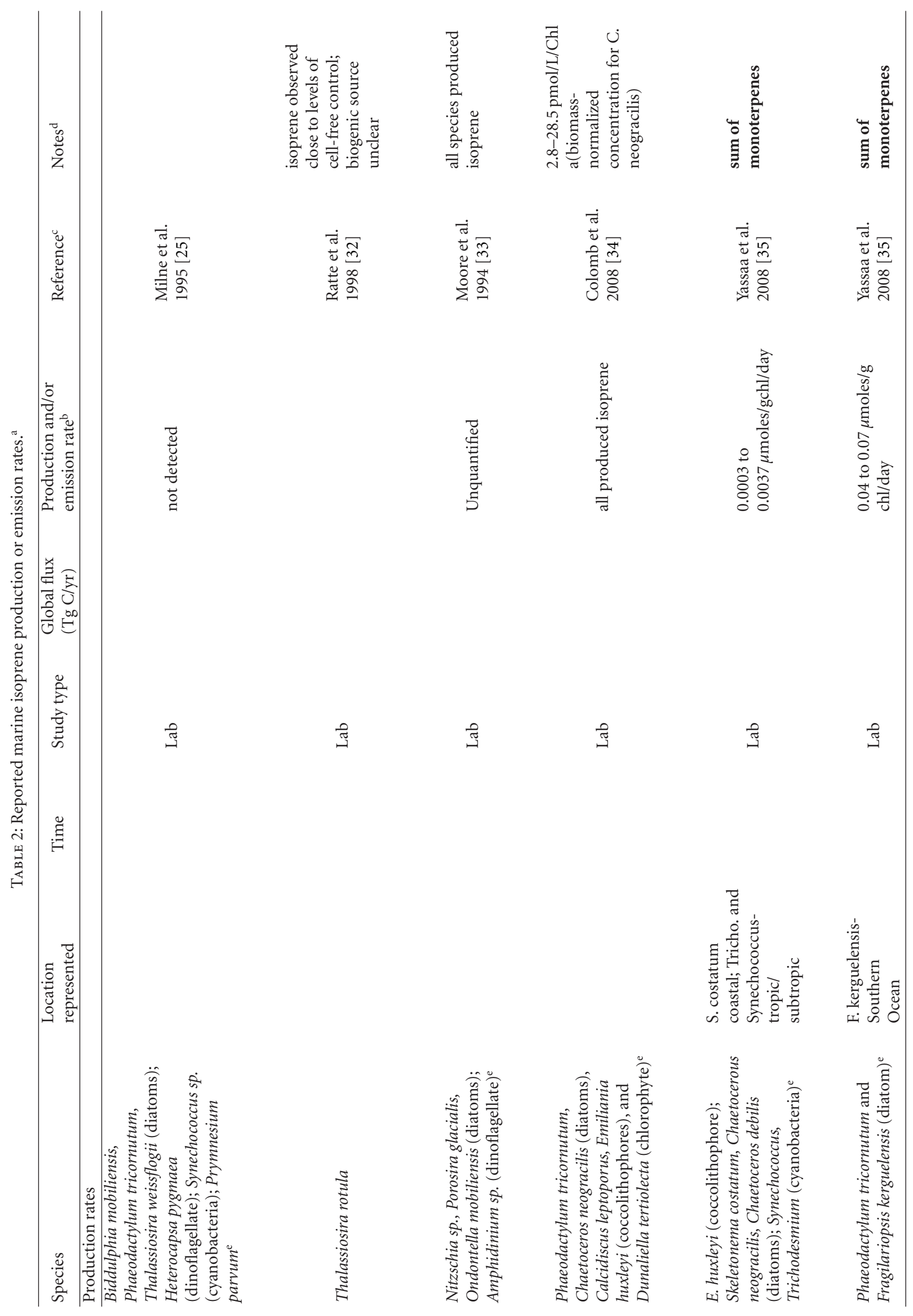




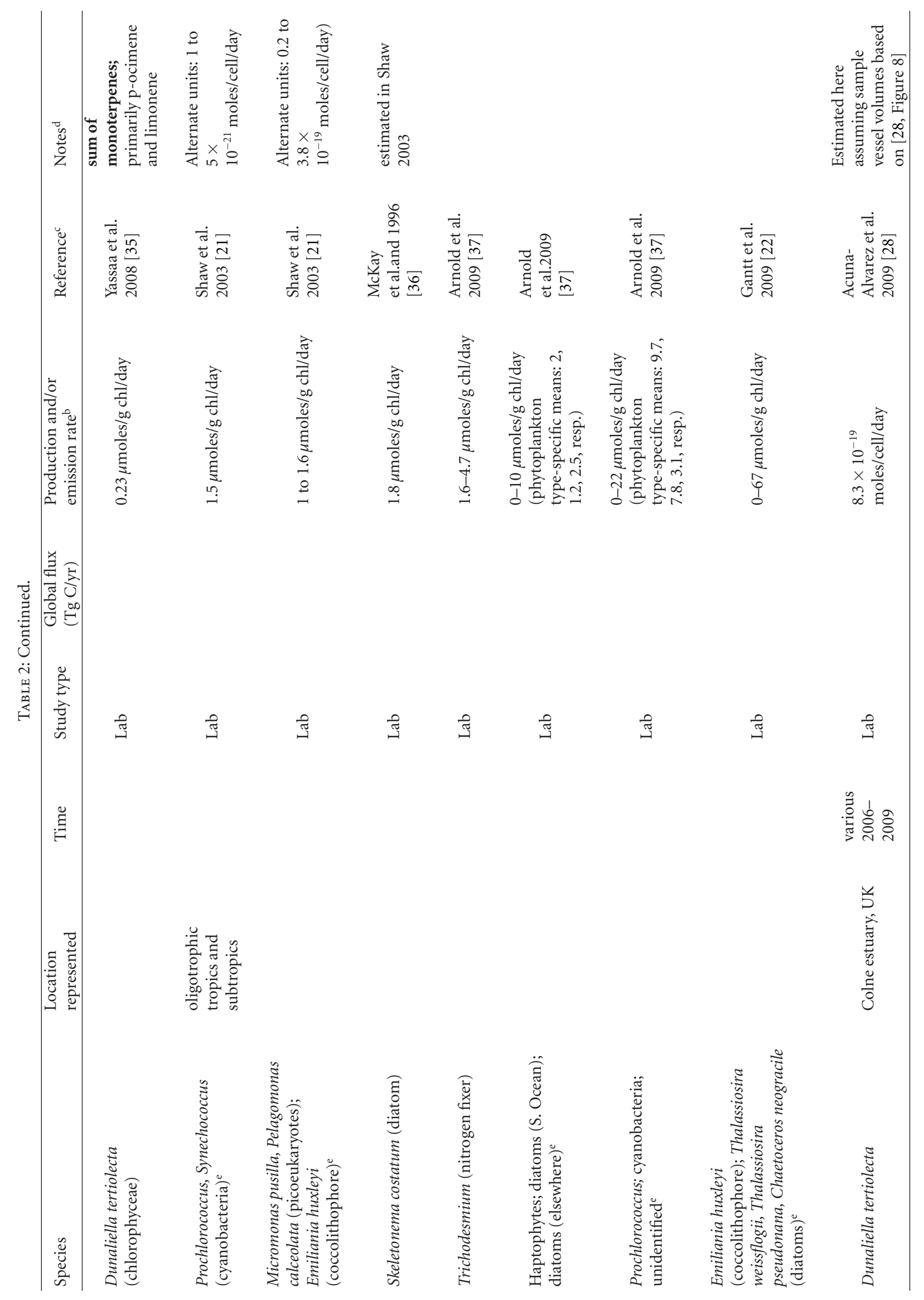


Advances in Meteorology

7
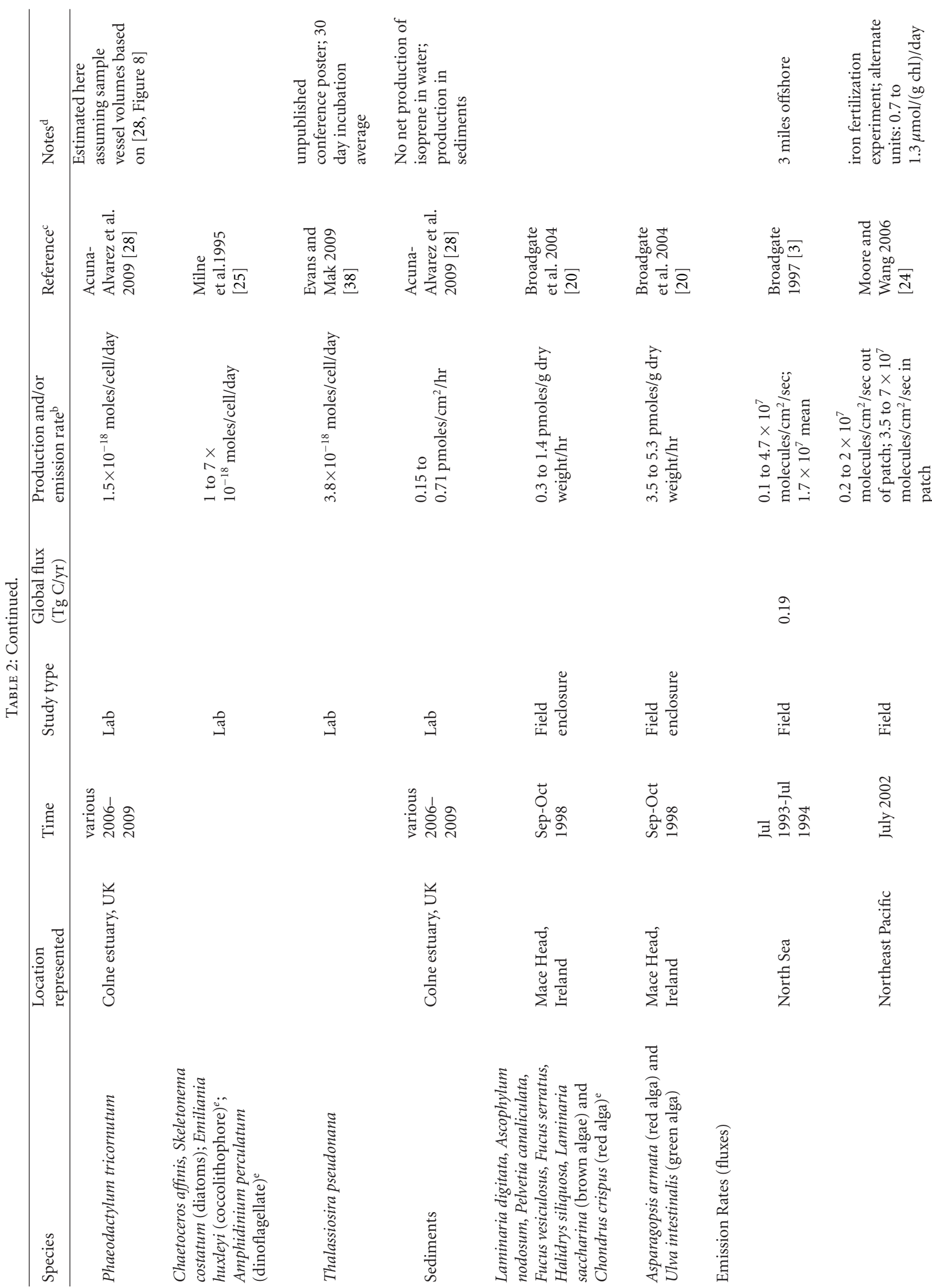

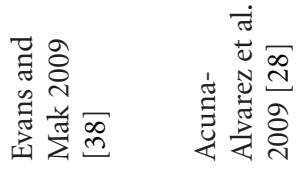

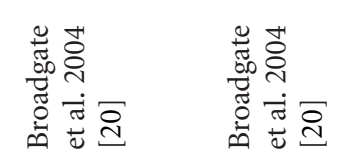

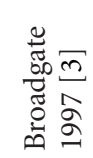

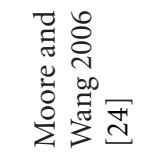

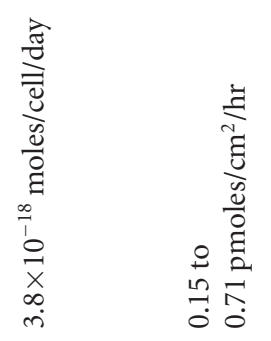

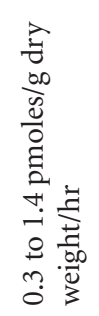

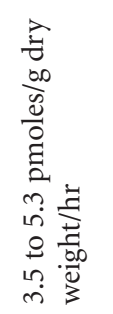

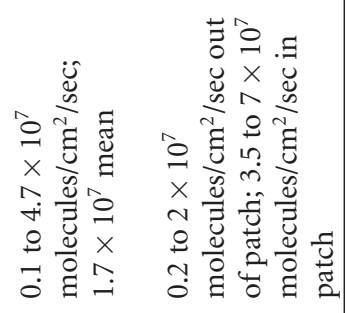

ฐี

웜

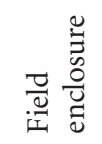

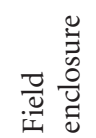

$\stackrel{9}{\circ}$

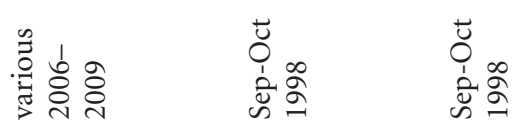

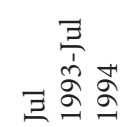

突

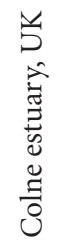

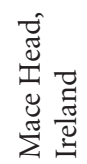

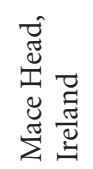

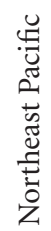

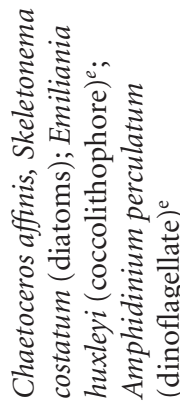

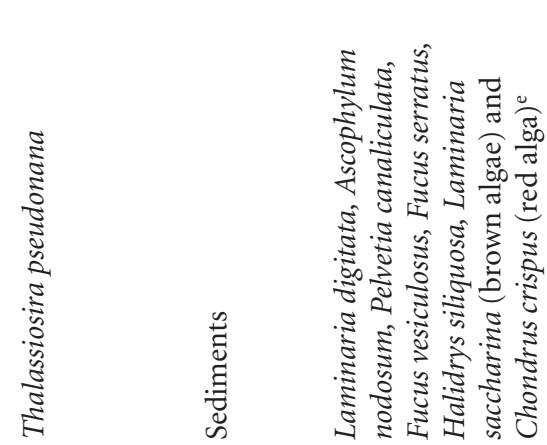

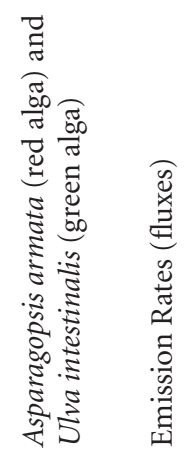

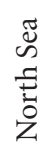

$\frac{\pi}{0,0}$

拿

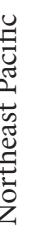

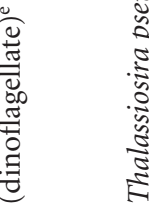

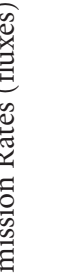




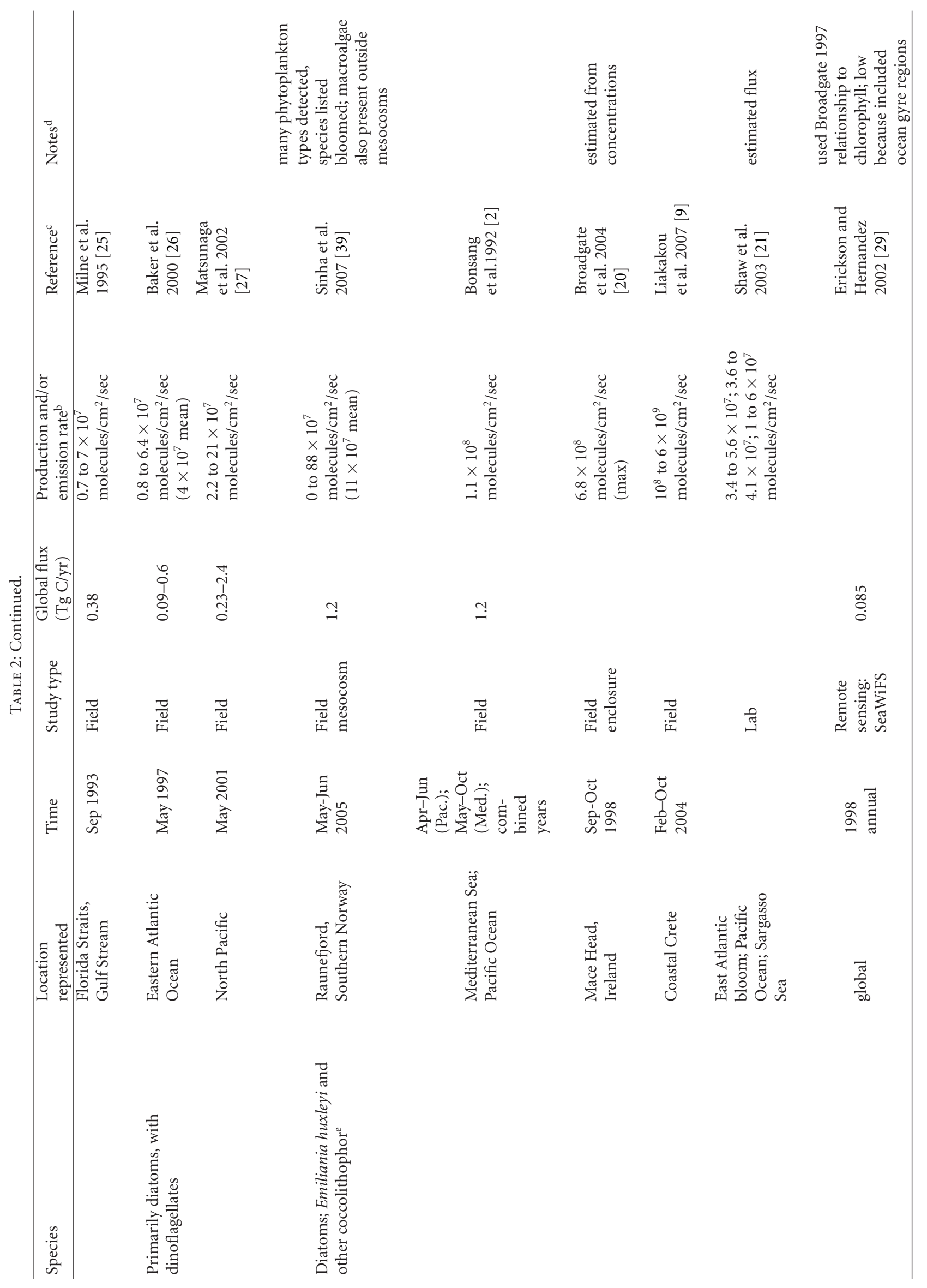




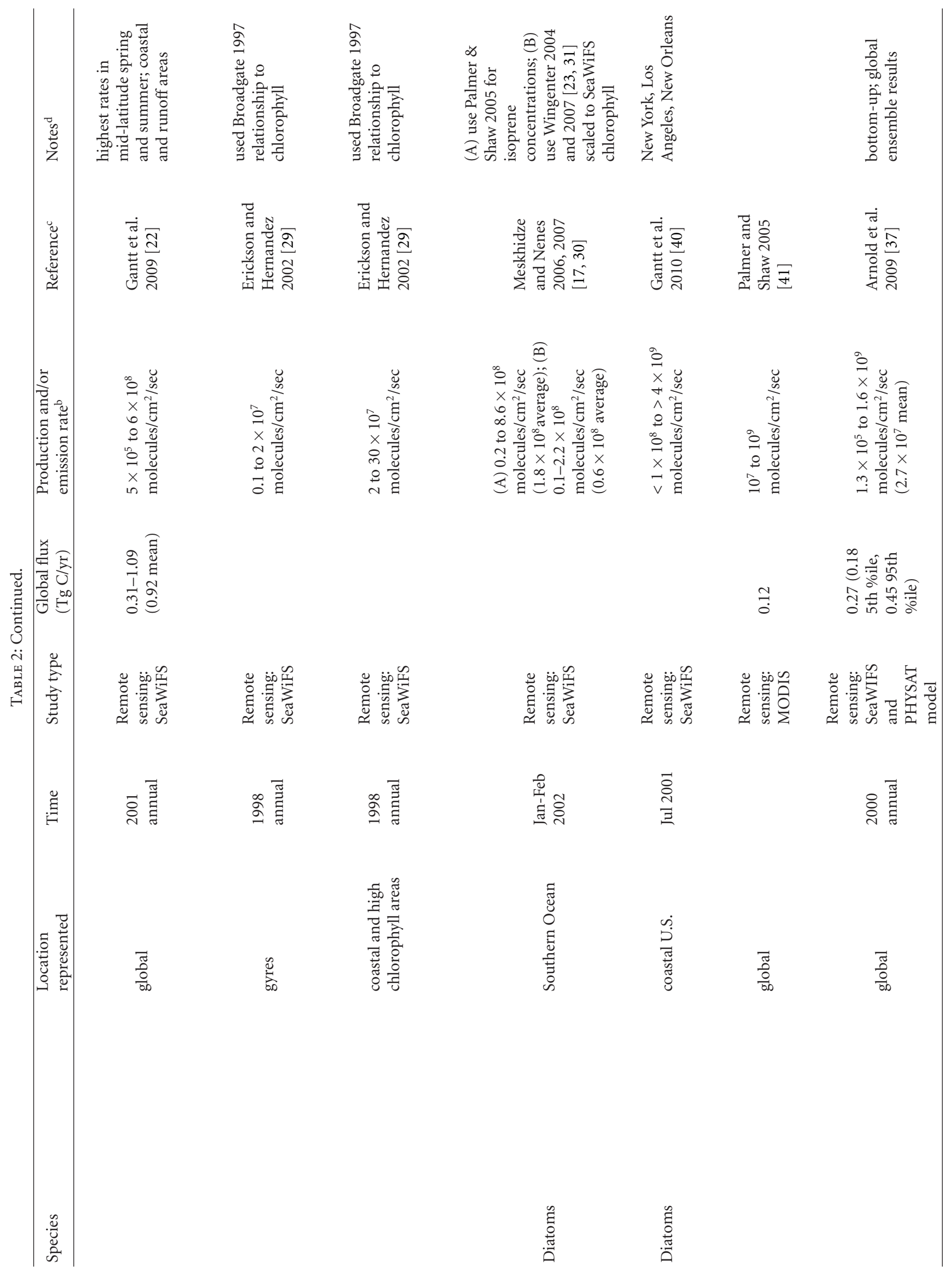




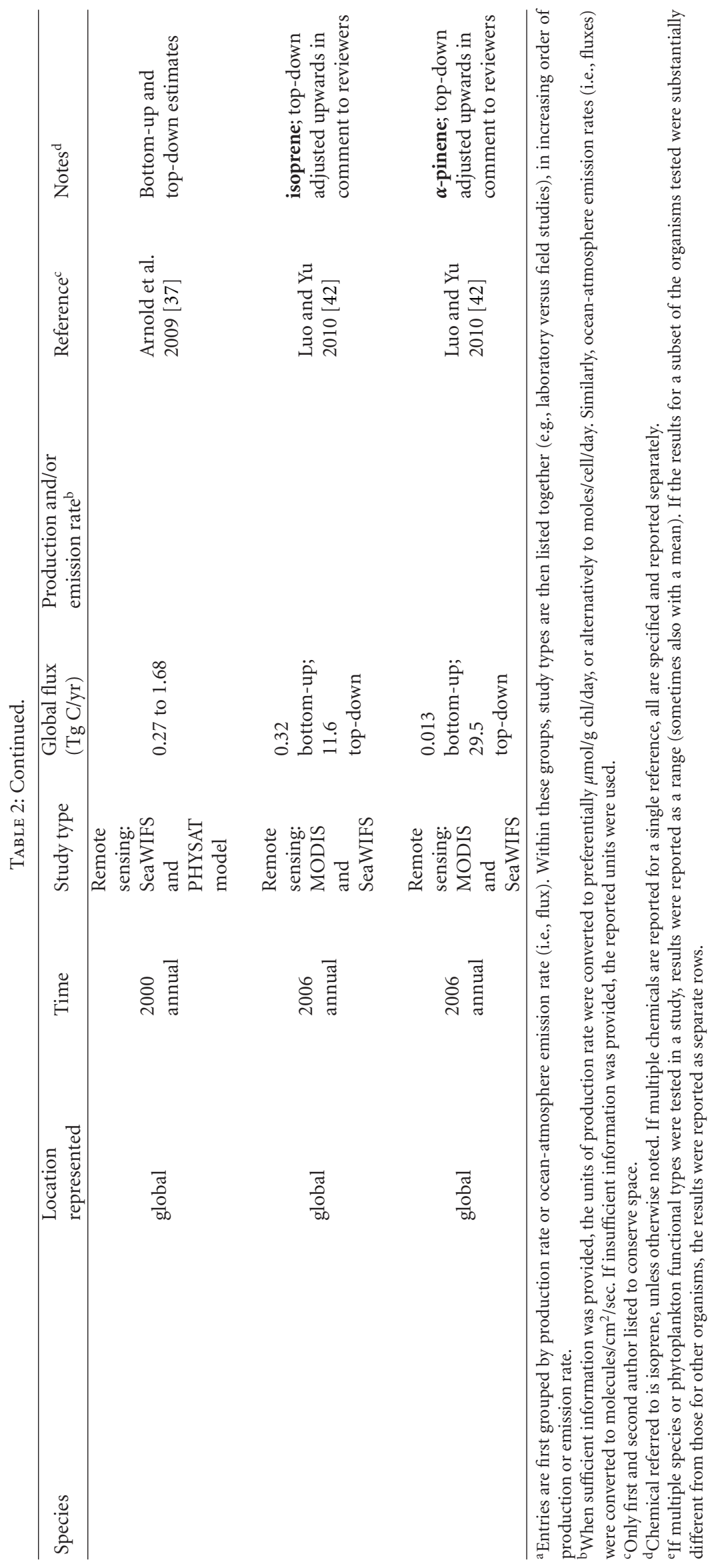




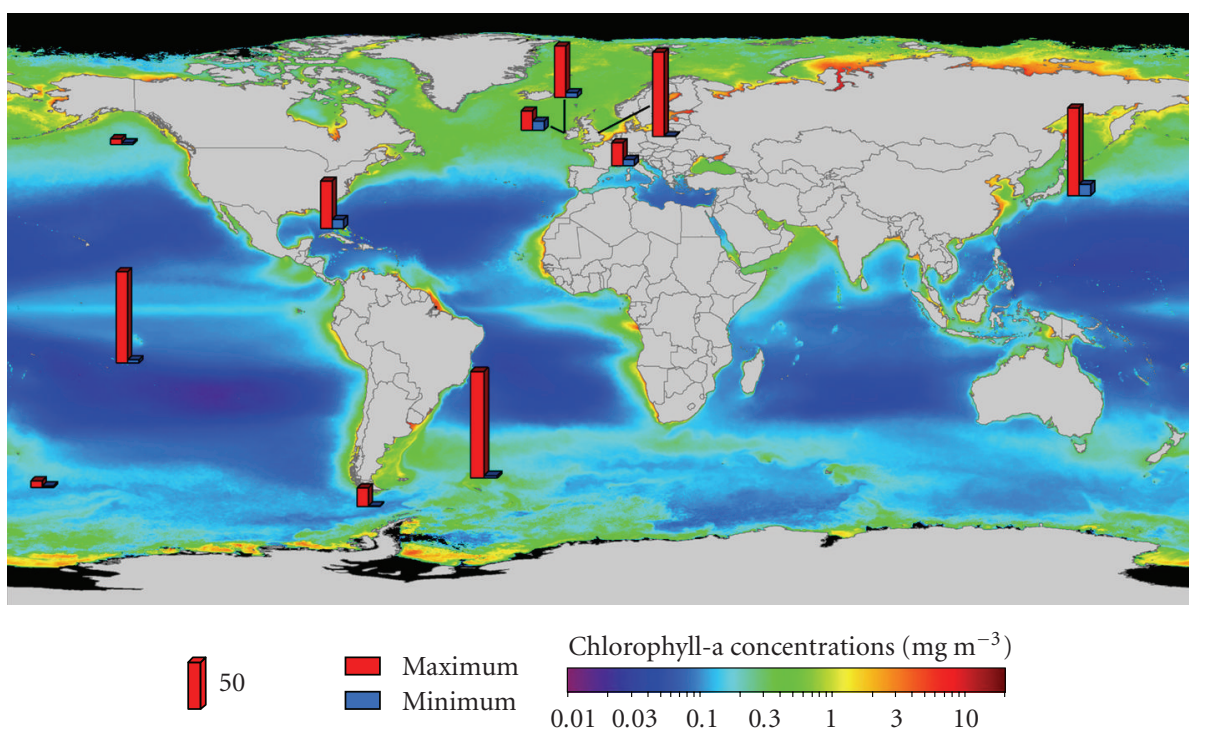

FIgURE 1: Marine Isoprene Seawater Concentrations. Concentrations in pmol/L. All values reported in the corresponding table are included, except for global modeling studies for which individual locations were not reported. Only "out of bloom" values reported for fertilization experiments. Representative lat./long. coordinates chosen when necessary. Figure background shows SeaWiFS retrieved surface [Chl- $\alpha$ ]. Figure 1 only: Two high points removed $[20,28]$ to bring all other points in range.

isoprene production rates for diatoms and coccolithophores and photosynthetically active radiation (PAR) showed consistency with these results, despite a limited number of light levels tested. In contrast, production rates dropped at higher temperatures. While these exact conditions may be linked to species-specific growth requirements and cannot be easily generalized to all species, the measurements of Shaw et al. [21] clearly show the importance of sunlight and water temperature on isoprene production rates by phytoplankton.

The impact of addition of both grazers and viruses on isoprene production rates by phytoplankton was also tested in separate experiments by Shaw et al. [21]. The presence of these other microorganisms was found to affect isoprene production only through the impacts of these organisms on phytoplankton cell counts. For example, the grazers ate the phytoplankton cells, and thus there were less phytoplankton available to produce isoprene, and thus less isoprene. However, the grazers themselves did not produce or consume isoprene. Shaw et al. [21] also showed that the presence of several selected species of heterotrophic bacteria did not impact production rates; that is, there was no evidence of isoprene production or consumption by these bacterial species.

Additional results by these authors showed that chlorophyll-normalized production rates were constant across the species tested. This fact, combined with low absolute production rates and percentages of fixed carbon loss to isoprene (approximately $10^{-4} \%$ for phytoplankton as compared to $0.5 \%-2 \%$ for higher plants; Shaw et al. [21]) suggested that isoprene may be emitted as a waste product. As the species tested by Shaw et al. [21] represent oligotrophic oceanic regions with low community growth rates, reported marine isoprene production rates might be expected to be lower than those for phytoplankton species representative of more nutrient-replete areas. More recently Arnold et al. [37] confirmed the previously observed linear relationship of isoprene with chlorophyll, although the slopes varied with species.

Laboratory isoprene emission rates of Colomb et al. [34] and Moore et al. [33] were not included in Table 2, as the detectable isoprene production could not be easily converted to units comparable to other studies.

3.2. Field Studies on Environmental and Physical Controls. As discussed above, a number of relationships have been observed between ambient concentrations of seawater isoprene and (1) chlorophyll concentration, (2) phytoplankton species, and (3) diel cycles (likely reflecting light and/or temperature variations) $[2,3,23-27,39]$. Despite the inability to explicitly test cause-and-effect of these parameters in the field, and the use of concentration rather than production rate, the results of these studies are broadly similar to the corresponding relationships to production rates observed in laboratory studies.

3.3. Effects of Phytoplankton Species and/or Functional Type. Isoprene production is dependent on the phytoplankton species or functional type, as well as changes in ambient conditions. Therefore, it is informative to review the specific effects that phytoplankton speciation may have on marine isoprene emissions. Table 2 lists 10 species (or genera with unspecified species) whose isoprene production rates have been measured across the various studies reviewed. Due to the paucity of studies on isoprene production by phytoplankton, results from both laboratory and field studies are included in this analysis when relevant. For five 


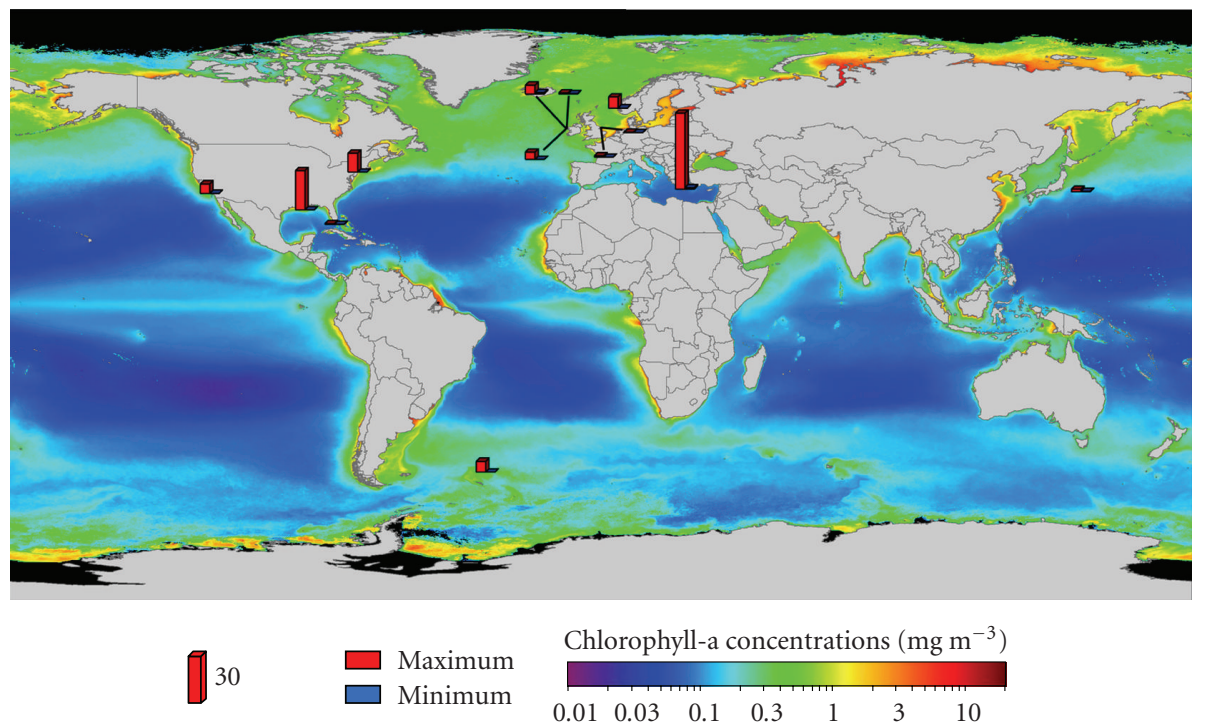

FIgURE 2: Marine Isoprene Flux Measurements and Estimates. Fluxes reported as $\times 10^{8}$ molecules $/ \mathrm{cm}^{2} / \mathrm{sec}$. Otherwise as for Figure 1 .

species/genera (Skeletonema costatum, Chaetoceros neogracilis, Thalassiosira pseudonana, Dunaliella tertiolecta, and Amphidinium sp.), isoprene production is always detected but the rates cannot be directly compared due to the lack of quantifiable or consistent units. In the case of Phaeodactylum tricornutum, Synechococcus sp., and Thalassiosira weissflogii, there are conflicting reports of detected production. This is likely due to a characteristic culturing choice or detection limit issue as in all cases the "not detected" value was from the same report [25]. The two species whose reported isoprene production rates have comparable units (Prochlorococcus, Emiliania huxleyi) have rates within a factor of 10 of each other.

In order to simplify the characterization of marine isoprene production, individual species have been grouped by phytoplankton functional type (PFT) as follows: chlorophytes, coccolithophores, haptophytes, cyanobacteria, nitrogen fixers, diatoms, dinoflagellates, picoeukaryotes, and unclassified species. Within several functional types, and specifically diatoms, the range of isoprene production rates was quite variable, ranging from zero to $4 \times 10^{-18}$ moles/cell/day (or $67 \mu \mathrm{mol} /(\mathrm{g} \mathrm{chl}) /$ day for a second diatom species), two of the highest production rates reported for any species. The coccolithophore and cyanobacteria production rates were within 2 orders of magnitude. Haptophyte and picoeukaryote production rates were similar within each group with the variation less than 1 order of magnitude, although only 2 studies for each PFT exist. The isoprene production rates for diatoms have been most extensively measured in previous studies based on the number of individual species tested. Due to the relative lack of available measurements, but high values for some production rates, we suggest the need for additional sampling of the chlorophyte, haptophyte, and dinoflagellate functional types.
3.4. Isoprene Production by Other Marine Organisms. In addition to the work just discussed on microalgae, isoprene measurements related to the presence of other marine organisms have been made. Broadgate et al. [20] measured isoprene concentrations in enclosed coastal rockpools which were filled with various macroalgal (e.g., seaweed) species. Isoprene in seawater increased 6-fold from dark to light periods, and up to 62-fold over the course of a sunny day. Increasing temperature also increased seawater isoprene concentration up to 10 -fold. These observations, in combination with increased fluxes during periods of ebbing tide, led the authors to hypothesize that seaweeds are similar to higher plants in that isoprene may contribute to their thermotolerance. Isoprene has also been detected in other studies of coastal waters inhabited by macroalgae [44].

Isoprene production by bacteria was also recently observed in estuary sediments at levels of 0.15 to $0.71 \mathrm{pmoles} / \mathrm{cm}^{2} / \mathrm{hr}$ [28]. However, the focus of the AcunaAlvarez et al. [28] study was on isoprene consumption, which will be described in the next section.

Aquatic plants of a higher order than phytoplankton, such as the sedges, mosses (e.g., Sphagnum sp.), grasses, and shrubs grown in the boreal and subarctic wetlands of Finland and Sweden, have also been shown to produce isoprene $[4,45-48]$. In both their physiology and isoprene production rates, these plants are more similar to terrestrial plants than algae. However, they share some traits with isoprene production by phytoplankton as well. Along with other marine and terrestrial biogenic isoprene producers, isoprene production in aquatic plants generally increases with light and temperature [46]. Nutrient availability also plays a role in isoprene production by these species; increasing nitrogen or phosphorus reduced isoprene emissions in both Phragmites australis and sedges [4, 48]. 
3.5. Summary of Isoprene Production Rates. In summary, isoprene production rates by phytoplankton and macroalgae have been shown (in laboratory and field work) to vary with plankton species, light level, temperature, and chlorophyll. Isoprene production is related to cellular chlorophyll content. The mean species-specific rates from 4 studies normalized by Chl-a concentrations $[21,22,36,37]$ are within one and a half orders of magnitude ( 1 to $70 \mu$ moles/(g Chl-a)/day). Production rates normalized to cell counts ranged over 4 orders of magnitude, from $1 \times 10^{-21}$ to $3 \times 10^{-18}$ moles/cell/day (Table 2). Only some studies have reported the rates in comparable units. We suggest that future work in this area use one or both of the following two units for reporting of production rates due to their simplicity and the fact that most of the necessary parameters are typically measured in moles/(g Chl-a)/day, or moles/cell/day. The first option is preferred as there is field and laboratory evidence that suggests isoprene production is related to cellular chlorophyll content, and certainly the biological synthesis process for chlorophyll consists of linking monomer isoprene units together [49]. In addition, such production rates would be able to be scaled by remotely-sensed chlorophyll data from satellites. A cell-normalized production rate is less optimal as it does not account for cell size, chlorophyll content, or photosynthetic activity, which all may act to influence isoprene production. The larger 4 order of magnitude range of production rates for the former units, as compared to 1.5 for the latter, clearly show the resulting imprecision. However, due to the many biological, chemical and physical parameters desired in biogenic trace gas emission studies, it is unfortunately true that many authors do not collect or report all desired information, such as chlorophyll content. Although we do not suggest that this is good practice, a simple cell count is often within the reach of most investigators, especially in laboratory settings, and would certainly serve as an improvement upon no standardized normalizing factor, which is not uncommon in the literature at this time.

\section{Marine Isoprene Losses in Seawater}

Although some evidence exists to demonstrate possible isoprene losses in seawater, very little is known about the main parameters controlling this loss. While the few bacterial species tested in laboratory work [21] were not suggested to exhibit consumption of marine isoprene due to statistically identical isoprene production rates regardless of the presence of heterotrophs, indications of consumption do exist from field work in the ocean water column. Depth profiles, taken over several weeks after an in situ iron fertilization experiment [24], qualitatively suggested that if biological consumption occurred in the water column it was at rates lower than production; this was based on expected influences of various sources and sinks on net production rate. A mesocosm study in a Norwegian fjord reported a relationship between increasing cell counts of Synechococcus sp. and decreasing ocean-atmosphere isoprene fluxes, implying that some phytoplankton species could actively consume isoprene [39]. It should be noted that the corresponding observed relationships between the cell counts of other phytoplankton species or functional types (Emiliania huxleyi, nanoplankton, picoplankton, and heterotrophic bacteria) and isoprene fluxes were positively correlated, suggesting biogenic sources. Most recently Acuna-Alvarez et al. [28] investigated isoprene consumption by bacteria in temperate (Mediterranean Sea), tropical (Indonesia), and coastal waters and sediments (Colne Estuary, U.K.). Consumption rates were higher for water samples (without sediment) that were spiked with lower levels of isoprene $(0.082 \mathrm{ppm})$ as compared to higher levels $(0.82 \mathrm{ppm})$. The authors showed that the regions with most rapid rates of isoprene consumption coincided with highest isoprene production areas (i.e., estuarine sediments as compared to waters). The dominant consumer species present in the sediments were Actinobacteria, Alphaproteobacteria, and Bacterdetes.

In contrast to biological consumption, only arithmetic estimates of chemical losses based on assumptions have been made. Due to the minimum amount of data available, both biological and chemical losses are still merely estimates and highly uncertain [22, 37, 40,41]. For example, Palmer and Shaw [41] estimated an isoprene lifetime due to bacterial consumption and chemical oxidation of $\sim 17$ and $\sim 19$ days, respectively. The bacterial consumption rate $(k=0.06 /$ day $)$ was assumed to be similar to that previously estimated for methyl bromide, while the chemical loss rates to $\mathrm{OH}$ and ${ }^{1} \mathrm{O}_{2}$ were also estimated (using typical seawater concentrations, as well as respective loss rates of $6 \times 10^{10}$ and $10^{6} \mathrm{M}^{-1} \mathrm{~s}^{-1}$ ). These values resulted in the hypothesis that seawater isoprene is removed primarily by air-sea exchange.

Only one field study [24] attempted to observe physical losses in the water column. A vertical diffusive flux was calculated as a diffusion coefficient times the isoprene concentration gradient across bottom of the mixed layer. The authors determined that there was a negligible diffusive flux from the subsurface isoprene maxima into the mixed layer, equal to only $3 \%-5 \%$ of the ocean-atmosphere flux. Measurements in the Florida Straits [25] demonstrated the lack of a strong diurnal pattern in depth profiles of isoprene concentration, suggesting that net water column losses of biological, chemical, and/or physical types occurred on time scales longer than production (which occurs during the day).

\section{Isoprene Mixing Ratios in Coastal and Remote Marine Atmospheres}

Atmospheric mixing ratios of marine isoprene over the remote oceans, or at coastal sites for time periods determined to be unaffected by terrestrial sources, have been directly measured in a number of field campaigns to be as high as 300 pptv (Table 3 and Figure 3). These mixing ratios varied with time of day, season, and location.

Field studies performed in coastal environments will be reviewed first. In three studies by Lewis and colleagues $[7,8,50]$, strong diurnal isoprene variations were detected at the Cape Grim Baseline Air Pollution Station, Tasmania and the Mace Head Atmospheric Research Station, Ireland. In all cases sharp mid-day peaks were observed when winds came from the ocean over periods of several days. These 

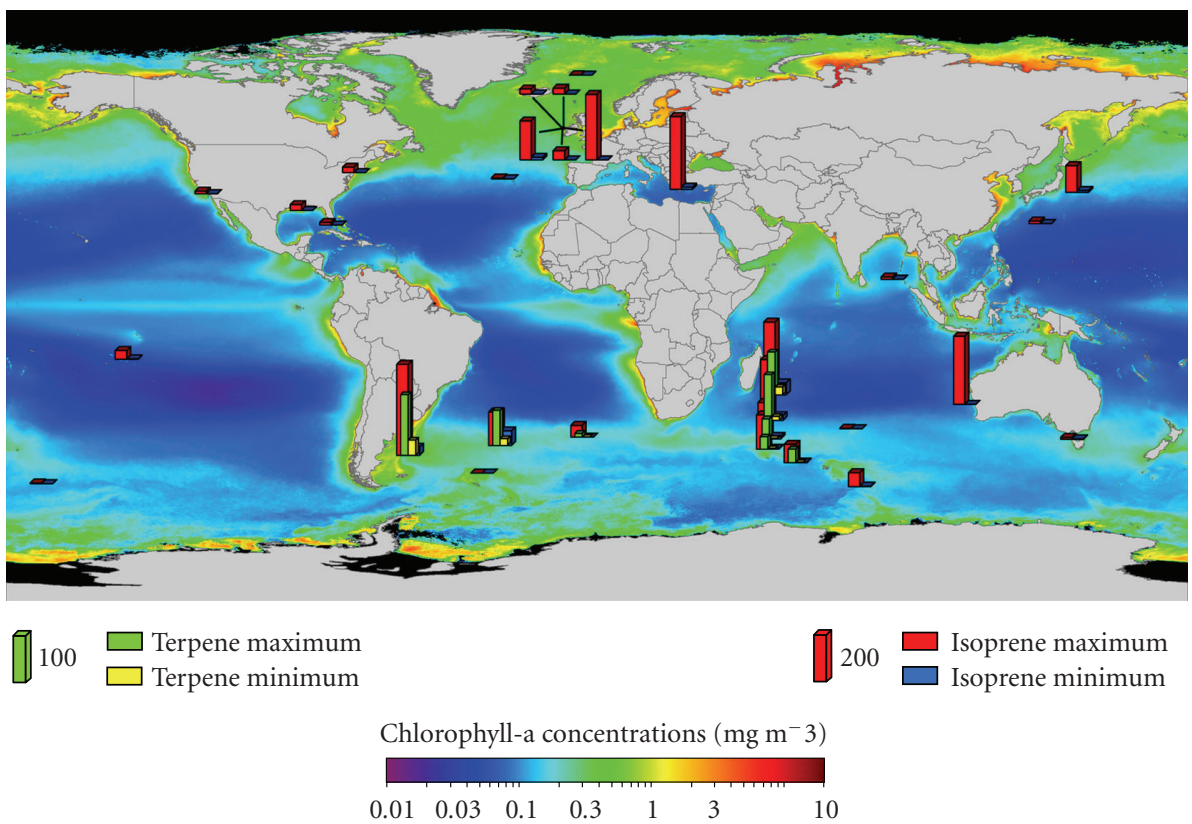

FIgure 3: Marine Isoprene and Monoterpene Atmospheric Mixing Ratios. Mixing ratios in pptv. Otherwise as for Figure 1. Figure 3 only: one high point [39] removed to bring other points in range.

peaks in marine boundary layer isoprene mixing ratios occurred earlier than the mid-afternoon isoprene peaks typically observed from terrestrial plant sources. Vertical profiles of isoprene from the ocean surface to $200 \mathrm{~m}$ were measured at a coastal site $5 \mathrm{~km}$ from Mace Head, Ireland by other authors [51]. Reported mean isoprene mixing ratios decreased from $68 \mathrm{pptv}$ near the surface to $14 \mathrm{pptv}$ at $200 \mathrm{~m}$ [51]. However, as the flux footprint encompassed open ocean as well as coastal and rocky land, the influence of coastal emissions on reported vertical profiles of isoprene in this study cannot be easily determined. Based on the ratios of isoprene abundance to that of its degradation products measured at Cape Grim, Australia, a local marine source of isoprene was also suggested in the Southern Ocean by Galbally et al. [52]. Long-term measurements at Finokalia sampling station on the island of Crete showed seasonal variability of isoprene in air masses identified as "marinederived" [9]. Highest mixing ratios (250-300 pptv) were observed from May through July. Isoprene mixing ratios in ambient air increased with light and temperature, in agreement with laboratory observations [21].

Isoprene mixing ratios have also been reported from field studies of the remote marine boundary layer. Yokouchi et al. [53] reported isoprene mixing ratios in the Southern Indian Ocean ranging from less than 10 to $280 \mathrm{pptv}$. This demonstrates the high spatial variability often observed in marine isoprene abundance. In other locations visited on this cruise, values of $>100 \mathrm{ppt}$ tended to be observed near tropical islands and those of $<100 \mathrm{ppt}$ when "open-ocean air masses" were measured. However, the Southern Indian Ocean sites' mixing ratios represented 2-day back trajectories over remote waters, which is much larger than the $<1$ to 4 hour estimated typical lifetime of isoprene over the ocean
[3, 40, 41, 52]. Colomb et al. [54] measured mixing ratios of isoprene and monoterpenes in the Southern Indian Ocean for air masses with 5-day marine back trajectories and found that isoprene was correlated with both the sum of isoprene secondary products (methacrolein and methyl vinyl ketone) and the sum of monoterpenes. Diurnal patterns of isoprene and monoterpene mixing ratios were observed with maxima at 10:00-12:00 local time; this is similar to the results of prior work at the Cape Grim and Mace Head coastal sites $[7,8,50]$. A consistent reduction in mixing ratios was observed as the ship track moved away from biologically active ocean waters. Matsunaga et al. [27] reported marine boundary layer isoprene mixing ratios in the western Pacific in a range of 30-70 pptv. They also reported other isoprene mixing ratios as high as $110 \mathrm{pptv}$ but believed them somehow influenced by terrestrial sources as they calculated very low $(<5 \mathrm{pptv})$ atmospheric mixing ratios that should result from the ocean-atmosphere fluxes they measured.

Review of the published literature shows that the higher isoprene mixing ratios of higher than several hundred pptv reported by some authors often occurred when sampling was performed nearer to coastal areas, suggesting the mixing rations may not be consistent with marine sources and subsequent atmospheric transformation. This is certainly possible; terrestrial boundary layer mixing ratios of isoprene can reach from several hundred to several thousand pptv. However, in almost all cases the authors have attempted to evaluate whether or not their methods have been influenced by terrestrial emissions (such as though the use of several day back-trajectories (e.g., [53]) or avoiding coastal areas [37]), and have concluded this was likely not the case. Another example is the work of Luo and Yu [42] who show that without the inclusion of oceanic emission 
TABLe 3: Ambient air mixing ratios of isoprene (or monoterpenes where noted). ${ }^{a}$

\begin{tabular}{|c|c|c|c|c|c|c|}
\hline Species & $\begin{array}{l}\text { Location } \\
\text { represented }\end{array}$ & Time & Study type & $\begin{array}{l}\text { Mixing ratio } \\
\text { (pptv) }\end{array}$ & Reference $^{\mathrm{b}}$ & Notes \\
\hline & $\begin{array}{l}\text { Tropical Pacific, } \\
\text { N. hemisphere }\end{array}$ & $\begin{array}{l}\text { Feb-Mar } \\
2006\end{array}$ & Field & $<1$ (mean) & $\begin{array}{l}\text { Galbally et al. } \\
2007[52]\end{array}$ & $\begin{array}{l}\text { aircraft data from } 0-2 \mathrm{~km} \\
\text { altitude }\end{array}$ \\
\hline & $\begin{array}{l}\text { Amsterdam } \\
\text { Island, S. Indian } \\
\text { Ocean }\end{array}$ & $\begin{array}{l}\text { Mar } \\
\text { 1986-May } \\
1987\end{array}$ & Field & $<2$ & $\begin{array}{l}\text { Bonsang et al. } \\
1992[2]\end{array}$ & $\begin{array}{l}\text { suspect canister losses, values } \\
\text { perhaps to } 10 \mathrm{ppt}\end{array}$ \\
\hline & Arctic Ocean & Aug 1999 & Field & $<2$ & $\begin{array}{l}\text { Hopkins et al. } \\
2002[66]\end{array}$ & $\begin{array}{l}53-81^{\circ} \mathrm{N} \text {; continuous Arctic } \\
\text { sunlight }\end{array}$ \\
\hline & Southern Ocean & Jan-Feb 2002 & Field & $<3$ & $\begin{array}{l}\text { Wingenter et al. } \\
2004[23]\end{array}$ & $\begin{array}{l}\text { Southern Ocean Iron } \\
\text { Enrichment Experiment } \\
\text { (SOFEX) }\end{array}$ \\
\hline & Pacific Ocean & $\begin{array}{l}\text { May-Jun } \\
1987\end{array}$ & Field & $<2-36$ & $\begin{array}{l}\text { Bonsang et al. } \\
1992[2]\end{array}$ & \\
\hline & $\begin{array}{l}\text { Cape Grim, } \\
\text { Tasmania }\end{array}$ & Jan-Feb 1999 & Field & $\begin{array}{l}1.8-7.9 \text { range } \\
(5.7 \text { day mean, } \\
<1.6 \text { night } \\
\text { mean })\end{array}$ & $\begin{array}{l}\text { Lewis et al. } 2001 \\
{[8]}\end{array}$ & marine winds \\
\hline & $\begin{array}{l}\text { Florida Straits, } \\
\text { Gulf Stream }\end{array}$ & Sep 1993 & Field & $<11$ & $\begin{array}{l}\text { Milne et al. } 1995 \\
{[25]}\end{array}$ & $\begin{array}{l}\text { also report modeled } \\
\text { concentrations }<1 \mathrm{ppt} \text { based } \\
\text { on calculated fluxes }\end{array}$ \\
\hline & $\begin{array}{l}\text { Cape Grim, } \\
\text { Tasmania }\end{array}$ & $\begin{array}{l}\text { Feb-Mar } \\
2006\end{array}$ & Field & 14 (mean) & $\begin{array}{l}\text { Galbally et al. } \\
2007[52]\end{array}$ & $\begin{array}{l}\text { methyl vinyl ketone and } \\
\text { methacrolein (isoprene } \\
\text { degradation products) }<2 \mathrm{ppt} \text {; } \\
\text { short isoprene lifetime }(<0.1 \\
\text { day) }\end{array}$ \\
\hline $\begin{array}{l}\text { Seaweed-filled } \\
\text { rockpools }\end{array}$ & $\begin{array}{l}\text { Mace Head, } \\
\text { Ireland }\end{array}$ & Sep-Oct 1998 & Field & $0-22(7$ mean $)$ & $\begin{array}{l}\text { Broadgate et al. } \\
2004[20]\end{array}$ & $\begin{array}{l}\text { estimated concentration based } \\
\text { on flux }\end{array}$ \\
\hline \multirow{5}{*}{$\begin{array}{l}\text { Diatoms and } \\
\text { haptophytes } \\
\text { dominant }\end{array}$} & $\begin{array}{l}\text { Mace Head, } \\
\text { Ireland }\end{array}$ & $\begin{array}{l}\text { July-Aug } \\
1996\end{array}$ & Field & $\begin{array}{l}0-25 \text { ( } 6.2 \text { mean } \\
\text { for SW winds, } \\
3.9 \text { mean for } \\
\text { NW winds) }\end{array}$ & $\begin{array}{l}\text { Lewis et al. } 1997 \\
{[7]}\end{array}$ & NW or SW winds \\
\hline & $\begin{array}{l}\text { Mace Head, } \\
\text { Ireland }\end{array}$ & $\begin{array}{l}\text { Apr-May } \\
1997\end{array}$ & Field & $0-37$ (2.6 mean $)$ & $\begin{array}{l}\text { Lewis et al. } 1999 \\
\text { [50] }\end{array}$ & polar/tropical/westerly winds \\
\hline & $\begin{array}{l}\text { Southern Indian } \\
\text { Austral Ocean }\end{array}$ & Dec 2004 & Field & $0-50$ & $\begin{array}{l}\text { Colomb et al. } \\
2009[54]\end{array}$ & $\begin{array}{l}\text { isoprene; } 40-49^{\circ} \mathrm{S} \text {; Zones IIb, } \\
\text { IIc, III; species suggested from } \\
\text { satellite data \& PHYSAT } \\
\text { model }\end{array}$ \\
\hline & Southern Ocean & $\begin{array}{l}\text { Dec } \\
\text { 1997-Mar } \\
1998\end{array}$ & Field & $\begin{array}{l}<1-57(13 \\
\text { mean })\end{array}$ & $\begin{array}{l}\text { Yokouchi et al. } \\
1999[53]\end{array}$ & $\begin{array}{l}\text { very variable concentrations; } \\
\text { highest levels south of } 45^{\circ} \mathrm{S} \\
\text { when winds from west and } \\
\text { south }\end{array}$ \\
\hline & North Pacific & May 2001 & Field & $\begin{array}{l}7.2-110 \text {; day } \\
\text { mean } 31, \text { night } \\
\text { mean } 70\end{array}$ & $\begin{array}{l}\text { Matsunaga et al. } \\
2002 \text { [27] }\end{array}$ & $\begin{array}{l}3.2 \text { pptv is estimated max } \\
\text { concentration supported by } \\
\text { measured oceanic flux }\end{array}$ \\
\hline
\end{tabular}


TABle 3: Continued.

\begin{tabular}{|c|c|c|c|c|c|c|}
\hline Species & $\begin{array}{l}\text { Location } \\
\text { represented }\end{array}$ & Time & Study type & $\begin{array}{l}\text { Mixing ratio } \\
\text { (pptv) }\end{array}$ & Reference $^{\mathrm{b}}$ & Notes \\
\hline \multirow{4}{*}{$\begin{array}{l}\text { Prochlorococcus } \\
\text { and haptophytes } \\
\text { dominant }\end{array}$} & $\begin{array}{l}\text { West Pacific, } \\
\text { Indian Ocean, } \\
\text { S.E. Asian Sea }\end{array}$ & $\begin{array}{l}\text { Nov-Feb; } \\
1996-1997\end{array}$ & Field & $\begin{array}{l}<10 \text { Indian } \\
\text { Ocean and East } \\
\text { China Sea; }>100 \\
\text { near islands and } \\
\text { Australia }\end{array}$ & $\begin{array}{l}\text { Yokouchi et al. } \\
1999[53]\end{array}$ & $\begin{array}{l}\text { highest levels were near land } \\
\text { (to } 286 \text { pptv); however, } \\
\text { near-Australia values had back } \\
\text { trajectories from Southern } \\
\text { Ocean, not land }\end{array}$ \\
\hline & $\begin{array}{l}\text { Southern Indian } \\
\text { Austral Ocean }\end{array}$ & Dec 2004 & Field & $40-150$ & $\begin{array}{l}\text { Colomb et al. } \\
2009[54]\end{array}$ & $\begin{array}{l}\text { isoprene; } 24-39.5^{\circ} \mathrm{S} \text {; Zones } \\
\text { I-IIa North of Aghula Front; } \\
\text { species suggested from satellite } \\
\text { data \& PHYSAT model }\end{array}$ \\
\hline & $\begin{array}{l}\text { Mace Head, } \\
\text { Ireland }\end{array}$ & Jul-Sep 2002 & Field & $<270$ & $\begin{array}{l}\text { Heard et al. } \\
2006[67]\end{array}$ & When winds from ocean \\
\hline & coastal Crete & Feb-Oct 2004 & Field & $10-300$ & $\begin{array}{l}\text { Liakakou et al. } \\
2007[9]\end{array}$ & $\begin{array}{l}\text { for marine-derived } \\
\text { back-trajectories; values }>100 \\
\text { from May-Aug }\end{array}$ \\
\hline $\begin{array}{l}\text { Prochlorophytes } \\
\text { and cyanobacteria }\end{array}$ & South Atlantic & $\begin{array}{l}\text { Jan-Mar } \\
2007\end{array}$ & Field & $\begin{array}{l}48 \text { max }(26 \\
\text { mean) before } \\
\text { bloom }\end{array}$ & $\begin{array}{l}\text { Yassaa et al. } \\
2008[35]\end{array}$ & $\begin{array}{l}\text { isoprene; species suggested by } \\
\text { pigments }\end{array}$ \\
\hline $\begin{array}{l}\text { Dinoflagellates, } \\
\text { diatoms. } \\
\text { pelagophytes }\end{array}$ & South Atlantic & $\begin{array}{l}\text { Jan-Mar } \\
2007\end{array}$ & Field & $\begin{array}{l}32-375(187 \\
\text { mean) during } \\
\text { bloom }\end{array}$ & $\begin{array}{l}\text { Yassaa et al. } \\
2008[35]\end{array}$ & $\begin{array}{l}\text { isoprene; species suggested by } \\
\text { pigments }\end{array}$ \\
\hline $\begin{array}{l}\text { Prochlorophytes } \\
\text { and cyanobacteria }\end{array}$ & South Atlantic & $\begin{array}{l}\text { Jan-Mar } \\
2007\end{array}$ & Field & $\begin{array}{l}14 \text { max }(5 \\
\text { mean) before } \\
\text { bloom }\end{array}$ & $\begin{array}{l}\text { Yassaa et al. } \\
2008[35]\end{array}$ & $\begin{array}{l}\boldsymbol{\alpha} \text {-pinene dominant } \\
\text { monoterpene; species } \\
\text { suggested by pigments }\end{array}$ \\
\hline $\begin{array}{l}\text { Dinoflagellates, } \\
\text { diatoms. } \\
\text { Pelagophytes }\end{array}$ & South Atlantic & $\begin{array}{l}\text { Jan-Mar } \\
2007\end{array}$ & Field & $\begin{array}{l}56-225(125 \\
\text { mean) during } \\
\text { bloom }\end{array}$ & $\begin{array}{l}\text { Yassaa et al. } \\
2008[35]\end{array}$ & $\begin{array}{l}\boldsymbol{\alpha} \text {-pinene dominant } \\
\text { monoterpene; species } \\
\text { suggested by pigments }\end{array}$ \\
\hline $\begin{array}{l}\text { Prochlorococcus } \\
\text { and haptophytes } \\
\text { dominant }\end{array}$ & $\begin{array}{l}\text { Southern Indian } \\
\text { Austral Ocean }\end{array}$ & Dec 2004 & Field & $20-100$ & $\begin{array}{l}\text { Colomb et al. } \\
2009[54]\end{array}$ & $\begin{array}{l}\text { sum monoterpenes; } \\
24-39.5^{\circ} \text { S; Zones I-IIa North } \\
\text { of Aghula Front; species } \\
\text { suggested from satellite data } \\
\text { and PHYSAT model }\end{array}$ \\
\hline $\begin{array}{l}\text { Diatoms and } \\
\text { haptophytes } \\
\text { dominant }\end{array}$ & $\begin{array}{l}\text { Southern Indian } \\
\text { Austral Ocean }\end{array}$ & Dec 2004 & Field & $0-40$ & $\begin{array}{l}\text { Colomb et al. } \\
2009[54]\end{array}$ & $\begin{array}{l}\text { sum monoterpenes; } 40-49^{\circ} \mathrm{S} \text {; } \\
\text { Zones IIb,IIc,III; species } \\
\text { suggested from satellite data } \\
\text { and PHYSAT model }\end{array}$ \\
\hline $\begin{array}{l}\text { Diatoms; Emiliania } \\
\text { huxleyi and other } \\
\text { coccolithophores }\end{array}$ & $\begin{array}{l}\text { Raunefjord, } \\
\text { Southern } \\
\text { Norway }\end{array}$ & $\begin{array}{l}\text { May-Jun } \\
2005\end{array}$ & $\begin{array}{l}\text { Field } \\
\text { mesocosm }\end{array}$ & $\begin{array}{l}<60-2400(180 \\
\text { median })\end{array}$ & $\begin{array}{l}\text { Sinha et al. } 2007 \\
\text { [39] }\end{array}$ & $\begin{array}{l}\text { many phytoplankton types } \\
\text { detected, species listed } \\
\text { bloomed; macroalgae also } \\
\text { present outside mesocosms }\end{array}$ \\
\hline Diatoms & Southern Ocean & Jan-Feb 2002 & $\begin{array}{l}\text { Remote } \\
\text { sensing } \\
\text { (SeaWiFS) }\end{array}$ & $\begin{array}{l}0.03-0.68(0.17 \\
\text { mean })\end{array}$ & $\begin{array}{l}\text { Meskhidze and } \\
\text { Nenes 2006, } \\
2007[17,30]\end{array}$ & $\begin{array}{l}\text { Palmer \& Shaw } 2005 \text { for } \\
\text { isoprene-chlorophyll } \\
\text { relationship; SOFEX scaled to } \\
\text { SeaWiFS chlorophyll } \\
\text { (Wingenter 2004, } 2007 \\
{[23,31] \text { ) }}\end{array}$ \\
\hline
\end{tabular}


TABle 3: Continued.

\begin{tabular}{|c|c|c|c|c|c|c|}
\hline Species & $\begin{array}{l}\text { Location } \\
\text { represented }\end{array}$ & Time & Study type & $\begin{array}{l}\text { Mixing ratio } \\
\text { (pptv) }\end{array}$ & Reference $^{\mathrm{b}}$ & Notes \\
\hline \multirow[t]{3}{*}{ Diatoms } & coastal U.S. & Jul 2001 & $\begin{array}{l}\text { Remote } \\
\text { sensing } \\
\text { (SeaWiFS) }\end{array}$ & $\begin{array}{l}10 \text { (midday } \\
\text { mean) NY and } \\
\text { NOL; } 2.5 \\
\text { (midday mean) } \\
\text { LA }\end{array}$ & $\begin{array}{l}\text { Gantt et al. } 2010 \\
{[40]}\end{array}$ & $\begin{array}{l}\text { New York, Los Angeles, New } \\
\text { Orleans }\end{array}$ \\
\hline & & 2006 annual & $\begin{array}{l}\text { Remote } \\
\text { sensing } \\
\text { (MODIS \& } \\
\text { SeaWIFS) }\end{array}$ & $0-280$ & $\begin{array}{l}\text { Luo and } \mathrm{Yu} \\
2010[42]\end{array}$ & Isoprene \\
\hline & & 2006 annual & $\begin{array}{l}\text { Remote } \\
\text { sensing } \\
\text { (MODIS \& } \\
\text { SeaWIFS) }\end{array}$ & $0-170$ & $\begin{array}{l}\text { Luo and } \mathrm{Yu} \\
2010[42]\end{array}$ & $\alpha$-pinene \\
\hline
\end{tabular}

${ }^{a}$ References are grouped by study type (e.g., field or remote sensing-based modeling studies), in roughly increasing order of mixing ratios.

${ }^{b}$ Only first and second authors were listed to conserve space.

fluxes in their model the atmospheric concentrations of $\alpha$-pinene and isoprene are essentially zero in the remote marine boundary layer, a result clearly at odds with a number of field studies (Table 3). The conclusion that terrestrial emissions are typically not being detected seems very reasonable when comparing multiday back trajectories against mixing ratios of chemicals whose lifetime is on the order of hours to a day. One case does exist for which contradictory results were found [27], suggesting that the sea-air flux was insufficient to explain the atmospheric isoprene mixing ratios. An explanation for these higher mixing ratios is still in question and should be an active research topic.

As a comparison to the field measurements and modeling results, we have also calculated the atmospheric mixing ratios based on typical seawater concentrations (Table 3 ) in two ways. First, we assume dynamic equilibrium between the water and atmosphere (i.e., simple Henry Law calculation). For seawater concentrations ranging from 1 to $100 \mathrm{pM}$ (typical for open ocean conditions), the corresponding atmospheric mixing ratio ranged from approximately $100 \mathrm{ppt}$ to $10 \mathrm{ppb}$. These could be considered maximum possible mixing ratios. However, various field observations have shown that isoprene is supersaturated in sea water by up to 3 orders of magnitude [2, 23-25], and so this simple approach is not representative and results in overestimated atmospheric mixing ratios. The second approach was to consider fluxes, which are a function of temperature, wind, boundary layer height, $\mathrm{OH}$ concentration, and so forth. In this case, for seawater isoprene concentrations of 1 to $100 \mathrm{pM}$ the resulting atmospheric mixing ratios ranged from approximately 0.15 to $15 \mathrm{ppt}$. These numbers are in agreement with modeling studies using CMAQ $[22,40,55]$.

\section{Marine Monoterpenes}

Marine terpenoids have been known to be produced by micro- and macroalgae, sponges, and corals, with particularly high rates in red and green seaweeds $[56,57]$. They are synthesized from the same precursors as terrestrial terpenes, but through different mechanisms, which results in a variety of different types of complex (not mono-) terpenes. Their ring structures can be quite different from the terpenes commonly reported as being emitted from terrestrial plants, and are often acyclic and quite halogenated because of high seawater concentration of halides [56,57]. These terpenes are generally thought to be used as a chemical defense mechanism against herbivory $[56,57]$.

While earlier field measurements of Sartin et al. [58] at coastal Mace Head, Ireland did not detect monoterpenes or sesquiterpenes in marine air and seaweed enclosures, observations of terrestrial-like marine monoterpenes (e.g., $\alpha$-pinene, limonene, $\mathrm{p}$-ocimene, and others) were recently reported in both laboratory cultures and shipboard measurements by Yassaa et al. [35]. Air mixing ratios of the sum of monoterpenes during a field campaign in the Southern Atlantic Ocean were as high as 150-200 pptv [35], which considering the short atmospheric lifetime of monoterpenes strongly suggested an oceanic source. The reported air mixing ratios of isoprene and $\alpha$-pinene were positively correlated, (especially in the region of an active phytoplankton bloom) indicating a similar source [35].

Monoterpene production rates from phytoplankton monocultures tested in the laboratory in the same manuscript were 3-4 orders of magnitude smaller than those for isoprene [35]. The tested species can be grouped into two categories, those for which isoprene emissions were a factor of 30-40 times higher compared to monoterpene 
emissions (for Prochlorococcus and diatom species), and those for which isoprene emissions were $>3000$ times higher than monoterpene emissions (for haptophytes, other cyanobacteria, and unidentified species) [42]. Higher isoprene than monoterpene emissions is also observed for terrestrial plants. In one compilation report, 80 species of higher plants (e.g., trees and shrubs) in 27 families for which both isoprene and monoterpene emissions were measured show isoprene to monoterpene emission rate ratios ranged over more than 3 orders of magnitude from 0.07-500 [59]. There was no discontinuity between low and high ratio species as there is with current minimal amount of phytoplankton data (e.g., 30-40 and >3000 ratios). Assuming the isoprene production rates from species tested by Yassaa represent similar percent of fixed carbon as previously suggested by Shaw et al. [21], monoterpenes could also be emitted through some sort of waste process (e.g., metabolic overflow or leak). Earlier field campaign reports of bacterial consumption of various terpenes do exist for Alaskan coastal seawater samples affected by spruce runoff [60], but even less is known about marine monoterpene consumption than production at this time.

\section{Modeling of Marine Isoprene Emissions and Mixing Ratios}

A variety of modeling techniques, ranging from simple photochemical box models to more complex global chemical transport models, have been used to investigate marine isoprene emissions and resulting atmospheric mixing ratios. This section will discuss the research performed using three different types of models: photochemical box models, global emission maps, and chemical transport models. Summaries of all modeled emission rates and atmospheric mixing ratios are depicted in Figures 2 and 3, respectively.

7.1. Photochemical Box Models. Several studies have used 0D photochemical box models $[9,25,26]$ to estimate marine boundary layer mixing ratios of isoprene and subsequent implications, such as impacts on oxidant mixing ratios. Milne et al. [25] used measured sea-to-air fluxes of isoprene to calculate atmospheric mixing ratios and diurnal variations that were consistent with their measured mixing ratios. Baker et al. [26] used measured fluxes offshore of western Ireland to determine resulting concentrations at the coastal Mace Head site after the 50-200 km transit. They found that the measured marine isoprene fluxes were insufficient to explain the 0-37 pptv of isoprene observed at Mace Head, suggesting potentially large isoprene sources closer to the shore. Palmer and Shaw [41] estimated that marine isoprene emissions represented $1 \%$ of $\mathrm{OH}$ losses in the remote marine boundary layer. A separate study [9] determined that the presence of marine isoprene on the island of Crete reduced nitrate radical mixing ratios by up to $25 \%$, increased daytime peroxy, organic oxy, and odd hydrogen radicals (i.e., $\mathrm{RO}_{X}$ ) by a factor of 4 , and increased nighttime hydroxyl $(\mathrm{OH})$ and hydroperoxy $\left(\mathrm{HO}_{2}\right)$ radicals by about $25 \%-30 \%$.
7.2. Emission Maps. The lack of widespread in situ measurements, combined with a poor understanding of the processes controlling production and loss of marine isoprene, has made it difficult to create reliable regional and global isoprene flux estimates. Fortunately, several novel modeling techniques based on remotely-sensed oceanic chlorophyll concentrations data have emerged. To estimate global marine isoprene fluxes, these models use surface chlorophyll- $a$ concentration $([\mathrm{Chl}-\alpha])$ as a proxy for marine isoprene production.

The first modeling attempt was by Guenther et al. [61], who assumed that the water concentration of various VOC, including isoprene, was linearly related to $[\mathrm{Chl}-\alpha]$, and combined it with a standard flux formulation based on surface wind speeds. Erickson and Hernandez [29] took a similar approach, but estimated water concentrations of isoprene based on observations of the isoprene-chlorophyll relationship [3]. They found that the seasonal flux on global scale was very consistent due to hemispheric seasonal differences. Palmer and Shaw [41] combined the isoprene-chlorophyll relationship of Shaw et al. [21] with the Moderate Resolution Imaging Spectroradiometer (MODIS) retrieved $[\mathrm{Chl}-\alpha]$ data to calculate marine isoprene flux. A steady-state water column model was assumed, including chemical losses and losses to bacteria, and air-sea exchange, with the latter to be a major controlling factor of oceanic lifetime of isoprene. Highest isoprene fluxes were shown to occur in high latitudes during times of elevated biological productivity. As mentioned above, due to the use of plankton species representative of oligotrophic oceans, the global fluxes reported by Palmer and Shaw [41] could be on the low end. This is described more fully in the next section on chemical transport models.

A new approach was taken by Arnold et al. [37] who combined satellite $[\mathrm{Chl}-\alpha]$ and satellite-derived phytoplankton type maps (using the PHYSAT model [62]) to estimate marine isoprene emission maps. This is described more fully in the next section. Gantt et al. [22] followed on the work of Arnold et al. [37] by creating a physically-based parameterization incorporating variable light intensity and euphotic zone depth, new laboratory isoprene production rates, and maps based on phytoplankton functional type (PFT). The authors found very high production rates in the tropics due to high solar radiation, even when [Chl$\alpha$ ] concentrations were relatively low. Two different PFT identification methods (the PHYSAT model [62] and the Nutrient Depleting Temperature model [63]) produced similar results. The emissions results suggested that $<1 \%$ of submicron OC was due to isoprene on an annual global scale. However, this study modeled for the first time hourly and peak marine isoprene fluxes. The model predicted large range of daytime-maximum to nighttime-minimum emissions also emphasized the importance of correctly capturing diurnal variations

7.3. Chemical Transport Models. While global emission maps provided some insight into the contributions of isoprene to OC formation, the alternate use of chemical transport models (CTMs) allows for incorporation of a wider range of 
controlling factors and can provide improved results. CTMs can also provide important constraints on emission fluxes (such as through top-down and bottom-up comparisons, and the fitting of models to observational data), and other atmospheric chemistry insights. The next 5 studies discussed involve combination of the remotely-sensed seawater chlorophyll data used for creating emission maps with the GEOSChem or CMAQ chemical transport models.

Spracklen et al. [64] found that 3-day back trajectoryweighted chlorophyll concentrations from Sea-viewing Wide Field-of-view Sensor (SeaWiFS) satellite instrument were highly correlated with atmospheric organic aerosol concentrations, suggesting an oceanic source of organic aerosol. By fitting observed organic carbon (OC) concentrations at Amsterdam Island, Mace Head, and the Azores, to global chemical transport model (GEOS-Chem) estimated OC, authors calculated an oceanic source of organic aerosol on the order of $8 \mathrm{Tg}$ OC/yr. Assuming that this OC was solely created from marine-derived isoprene, the authors calculated a required flux of $250 \mathrm{Tg}$ isoprene/yr. This is several orders of magnitude higher than current estimates. Similarly, applying an assumption of a 3\% isoprene yield of SOA (as did Spracklen et al. [64]) to the SOA flux estimates of Roelofs [65], the required isoprene flux would be a factor of 3-5 times higher than $250 \mathrm{Tg}$ isoprene/yr, suggesting additional sources of SOA precursors besides isoprene are needed to match the observed and/or estimated OC concentrations.

Arnold et al. [37] combined new satellite maps of PFT created from SeaWiFS data and the PHYSAT model [62], with new lab measurements of isoprene production rate to improve bottom-up global estimates of isoprene flux. Probability density functions of production rates were created for each PFT to account for large range of measured values and propagated through the global emission calculation. Bottom-up fluxes were insufficient to account for isoprene measurements in ambient air. The authors also used a "top down" approach by scaling the flux to minimize model bias. The two approaches had dissimilar results, likely due to a number of uncertainties including the limited amount of ambient and laboratory data, climatology, and retrievals. The results provided "top-down" fluxes in the same range as previously published values, good agreement with a selection of measured fluxes in the Atlantic, Norwegian Sea, and Southern Ocean, and a significant improvement over Palmer and Shaw [41] flux estimates in the Pacific. Flux estimates of Arnold et al. [37] from the top-down results also indicated that isoprene has an insignificant role $(<1 \%)$ in forming marine organic aerosol by secondary processes.

Gantt et al. [40] performed the first full regional modeling study of marine isoprene in coastal areas, by focusing on the continental United States. Marine isoprene emissions were found to have a minor role on air quality in coastal urban areas, resulting in $<1 \%$ changes in $\mathrm{SOA}$ and $\mathrm{O}_{3}$ concentrations. It was shown that the diurnal pattern of isoprene mixing ratios and fluxes are not the same because of the photochemical loss occurring during the daytime. A more recent study by the same authors [55] included marine isoprene, monoterpenes, and primary organic aerosol emissions. They found that over the remote ocean as well as coastal regions, marine isoprene and monoterpenes contribute $<10 \%$ of total marine organics aerosol concentration through SOA formation and increase ozone concentrations by $0.5 \%$.

The most recent isoprene [37] and monoterpene [35] production rate measurements were used in a global modeling study by Luo and Yu [42]. They used both bottomup and top-down methods of estimating global ocean emissions of $\alpha$-pinene and isoprene. Using the bottom-up method of Arnold et al. [37], which was based on surface flux measurements, resulted in emissions of $0.013 \mathrm{Tg} \mathrm{C} / \mathrm{yr}$ of $\alpha$-pinene and $0.32 \mathrm{Tg} \mathrm{C} / \mathrm{yr}$ of isoprene. The $\alpha$-pinene emissions are much smaller than isoprene emissions due to their lower production rates, as discussed previously in Section 6 . The top-down method added solar radiation and gas transfer terms to the parameterization of emission flux used in the bottom-up estimates, and model was then fit to observed atmospheric mixing ratios in the Southern Ocean [35]. In this way, estimates of the emissions necessary to match the observations were determined to be $29.5 \mathrm{Tg} \mathrm{C} / \mathrm{yr}$ and $11.6 \mathrm{Tg} \mathrm{C} / \mathrm{yr}$ for $\alpha$-pinene and isoprene, respectively. These top-down estimates are by far the largest reported for isoprene, and are even larger for $\alpha$-pinene. For example, the corresponding top-down estimate of isoprene emissions from Arnold et al. [37] was $1.7 \mathrm{Tg} \mathrm{C} / \mathrm{yr}$. This suggests that $\alpha$-pinene emissions from the top-down method could be significant to global budgets, and that subsequent SOA formation from $\alpha$-pinene may be a significant contributor to OC in marine environments.

While both the top-down and bottom-up methods of Luo and Yu [42] are subject to high uncertainties, there is a clear discrepancy in the results, particularly for $\alpha$ pinene. The authors suggest this may be due to incomplete understanding of the phytoplankton species that produce these chemicals and resulting production rates (bottomup method), or the emission parameterizations, model spatial resolutions, and assumed homogeneity of mixing ratios throughout entire height of boundary layer (top-down method). It is not clear which method may be more in error. Inclusion of only the bottom-up emissions estimates into the model was not able to replicate the high atmospheric mixing ratios observed [35], but use of surface mixing ratios throughout entire model boundary layer grid cells may overestimate the top-down emission fluxes. When the authors assume a vertical decay they estimate emissions as low as $10-15 \mathrm{Tg} \mathrm{C} / \mathrm{yr}$ for $\alpha$-pinene and $4-6 \mathrm{TgC} / \mathrm{yr}$ for isoprene. If any of these top-down estimates are correct, additional sources (e.g., additional phytoplankton species that produce these chemicals, or increased production rates) are needed to account for the ocean boundary layer mixing ratio observations [35].

Overall, the model estimates of global ocean isoprene fluxes range from $1 \times 10^{5}$ to $4 \times 10^{9}$ molecules $/ \mathrm{cm}^{2} / \mathrm{sec}$, approximately in the same range as for field observations and extrapolations from laboratory studies $\left(1 \times 10^{6}\right.$ to $\left.6 \times 10^{9}\right)$, but extending to lower values. Coastal regions were found to have greater isoprene fluxes compared to the open ocean areas $[9,28,40]$, although the impact of marine isoprene on local photochemistry and air pollution is predicted to be small $[40,55]$. 


\section{Current Issues}

This review of the literature on marine isoprene and monoterpenes demonstrates the progress made over the past 20 years since Bonsang et al. [2] first reported isoprene measurements in the oceans. A small body of knowledge now exists on the relevant organisms, major controlling factors for production and emissions, and potential impacts on atmospheric chemistry and SOA production. Despite this, knowledge gaps still exist which limit our ability to assess the global and regional effects of marine emissions.

Despite an increasing amount of recent research interest, the data available on production rates and ambient fluxes is insufficient to elucidate the mechanisms behind marine isoprene production, and to constrain the magnitude of ocean-atmosphere isoprene flux. In some cases, measured fluxes were insufficient to explain atmospheric mixing ratios present at, or somewhat downwind of, the measurement locations [26, 27]. For example, measured fluxes in the North Pacific support an ambient mixing ratio of $3.2 \mathrm{pptv}$, while the measured marine boundary layer mixing ratios were typically between 30-70 pptv [27]. These discrepancies could be due to the heterogeneity of production and loss processes. Considering the lack of understanding of these process mechanisms, it could also be attributed to inadequate parameterizations of the mechanism within the model.

Similarly, a large disconnect also exists between bottomup and top-down emissions estimates determined from use of more complex model calculations. Predicted fluxes or mixing ratios from bottom-up methods can often not account for observed values or scaled values [26, 37, 42]. In one study this discrepancy was much larger for $\alpha$-pinene than isoprene, which may be due to the single set of $\alpha$ pinene measurements available [35]. Other reasons for these discrepancies include misclassification or omission of certain phytoplankton species in the models, including incorrect characterization of high production rates, a lack of reliable ambient data, inaccurate emission parameterizations, insufficient model spatial resolutions, assumed homogeneity of mixing ratios throughout entire height of boundary layer, a reliance on satellite $[\mathrm{Chl}-\alpha]$ retrievals which may not accurately represent the chlorophyll concentrations that can influence isoprene or monoterpene emissions (e.g., may not sense chlorophyll from the full water depth that is ventilated), different phytoplankton communities suggested by PHYSAT than actually exist in the ocean, or a combination of all these uncertainties. It has been suggested by some authors that certain studies may have been influenced by isoprene abundances in terrestrial air masses passing over the ocean. However, as discussed previously due to lack of air mass contact with land within the short chemical lifetimes of these gases, coastal influence was ruled out for most open-ocean marine isoprene mixing ratio measurements. Even if some of these bottom-up fluxes are overestimated due to terrestrial influence, this would only act to mitigate the top-down and bottom-up flux discrepancies.

Isoprene has been suggested as a possible precursor of marine SOA based on the magnitude and direction of its ocean-atmosphere flux and established SOA formation mechanisms. Several recent estimates suggest the global isoprene flux is too small to account for a majority of marinederived organic aerosol. However, exceptions may occur when submicron OC, short time scales (e.g., peak emission hours), certain regions (e.g., tropics), or local scale impacts are considered [22, 40, 55]. Estimates from the recent modeling work of Luo and $\mathrm{Yu}$ [42] suggest large oceanic emission fluxes for $\alpha$-pinene $(29.5 \mathrm{TgC} / \mathrm{yr})$ and isoprene (11.6 TgC/yr), which are larger than most, but not all, estimates of global ocean submicron primary OC emissions $[22,64,65,68]$. Combined with the inherent heterogeneity of ocean fluxes, the $\alpha$-pinene emissions may be sufficiently high (in combination with its higher reactivity and SOA yield than for isoprene), to be considered an important source of submicron marine SOA. Furthermore, organic vapors from marine sources of VOC have been implicated to aid nucleation events and growth of ultrafine particles in coastal environments $[69,70]$. A month-long intensive measurement campaign conducted at a remote coastal site south of the Great Barrier Reef on the east coast of Australia revealed coastal nucleation events in clean, marine air masses on $65 \%$ of the days. The timing of the events (starting 10:00 local time and continuing for $1-4 \mathrm{hrs}$ ) as well as environmental conditions for the onset of nucleation (solar intensity above $1000 \mathrm{Wm}^{-2}$ and $\mathrm{RH}<60 \%$ ) are consistent with requirements for elevated marine VOC emissions. The measurements for volatility and hygroscopic properties of freshly nucleated particles suggested that the condensation of sulfate and/or organic vapors was most likely responsible for driving particle growth [70]. A different approach to investigating isoprene as a marine SOA precursor was taken by Claeys et al. [71]. Ambient measurements of chemical markers of isoprene-derived SOA, as determined for terrestrial environments, were taken in marine air at Amsterdam Island in the Southern Ocean. Due to the absence of sulfate esters of tetrols (isoprene-specific markers), it was concluded that the source of the water soluble component of marine organic aerosols at the site may be attributed to the oxidation of primary emissions of phytoplankton biomass rather than isoprene. However, this may not be true of other geographical areas. It was previously found that despite the abundance of high isoprene-producing diatoms at Amsterdam Island, air mixing ratios of isoprene were $<2$ pptv with an expected maximum of $<10$ pptv $[2,54]$. Repetition of this work in locations where isoprene has been determined to be more abundant is needed to conclusively determine the source-attribution of marine organic aerosols.

\section{Suggested Future Directions}

Over the past decade, laboratory and field measurements, satellite remote sensing, and modeling efforts have substantially improved our understanding of the temporal and spatial distribution of marine isoprene and monoterpene emissions and their potential effects on marine aerosol number concentration and chemical composition. However, an improved understanding of the impacts of marine isoprene emissions requires additional data collection from several 
directions. Several suggestions for future work are described below.

(1) Few laboratory (e.g., bottle) studies of isoprene production have been reported, and more are necessary to explain production mechanisms, confirm the dependence of emission rates on phytoplankton speciation, and determine the conditions that promote and inhibit production. Both laboratory measurements and field studies have their limitations. It is often very hard to mimic actual ambient conditions in the laboratory, and field campaigns suffer from their geographically sparse coverage and shortduration that may lead to missed events or conditions of interest due to changing natural conditions and the inherent heterogeneity of biogenic trace gas production and emission processes. Models can provide a global and highly temporal perspective, but require field and laboratory measurements for validation. Therefore, it is recommended that all these approaches be pursued simultaneously in future studies.

(2) Following on the first suggested research direction, it will also be important to pursue experiments that retain group dynamics of microorganism communities while measuring production rates from phytoplankton species, or identifying controlling factors thereupon. The few studies that have looked into such organism combinations have found evidence to suggest some interactions exist. These include predator-prey impacts in laboratory studies [21], and in situ shifts microorganism community structure that correlates with changes in ocean emission rates [23]. The analysis of production rate by phytoplankton species or functional type also clearly demonstrates a wide variety of responses by different species that can coexist. Testing of group dynamics can be done through controlled laboratory experiments, or in mesocosm studies which allow whole ecosystem testing [39].

(3) Approximately 27 phytoplankton species in 9 PFTs have already been tested for isoprene or monoterpene production capabilities. However, the resulting production rates are highly variable, ranging over several orders of magnitude. Future testing should focus on several key species or PFTs. First, due to the lack of measurements, but large values for some production rates, additional sampling of the charophyte, haptophyte, and dinoflagellate species is recommended. Second, species typical of the tropics and remote oceans should be tested, due to the importance of isoprene and monoterpene emission impacts on atmospheric chemistry and aerosol formation potential in these biogeographical regions. For ease of comparison across studies, we recommend one of the following production rate units be used for future reporting of production rates: (1) moles/g Chl- $\alpha$ /day or (2) moles/cell/day.

(4) Work on biogenic production of trace gases by aquatic plants other than phytoplankton suggests that nutrient availability can have an effect on isoprene emissions $[4,48]$. Preliminary results from Evans and Mak [38] suggest that isoprene production by Thalassiosira pseudonana decreased with reductions of provided phosphate, nitrate, and silica. The importance of this relationship between nutrients and emissions requires further investigation.
(5) Due to their high SOA forming potential, and the very high initial estimates of emission rates recently published, additional field and lab work on marine monoterpene emissions is warranted.

(6) For the assessment of water column isoprene losses, information on both chemical and biological consumption is needed. However, as several studies have suggested that ocean emission rates cannot always account for air mixing ratios in the marine boundary layer, these loss processes may be much more important in estuaries and near coastal regions than in the open oceans.

(7) Additional measurements of isoprene-specific tracers in areas of higher isoprene emissions and air mixing ratios could help to constrain assessments of impact on SOA.

\section{Conclusions}

Isoprene and terpene emissions are of interest in remote marine environments as sources of SOA, contributors to photooxidant chemistry, and as biogenic tracers. The amounts and impacts of these emissions on the atmosphere is not well constrained, but may be potentially important for future climate and air quality research. These uncertainties associated with marine isoprene emissions and its effects on local photochemistry and SOA formation can only be answered with additional data from a variety of sources including laboratory, field, and modeling studies. All three approaches should continue concurrently, with a focus on phytoplankton speciation, nutrient-dependence, chemical and biological water-column loss, and other factors that can affect emissions. Because of the complex nature of this water-air-biological system, it is important to make trace gas measurement in air and water phases in concert with a suite of detailed biological and environmental measurements such as aerosol chemical composition and size distribution, meteorological parameters (e.g., light, wind, and temperature), physical water parameters, pigment concentrations, and cell counts of dominant phytoplankton species.

\section{Acknowledgement}

N. Meskhidze would like to acknowledge the support by the Office of Science (BER), U.S. Department of Energy, Grant no. DE-FG02-08ER64508.

\section{References}

[1] A. Guenther, T. Karl, P. Harley, C. Wiedinmyer, P. I. Palmer, and C. Geron, "Estimates of global terrestrial isoprene emissions using MEGAN (Model of Emissions of Gases and Aerosols from Nature)," Atmospheric Chemistry and Physics, vol. 6, no. 11, pp. 3181-3210, 2006.

[2] B. Bonsang, C. Polle, and G. Lambert, "Evidence for marine production of isoprene," Geophysical Research Letters, vol. 19, no. 11, pp. 1129-1132, 1992.

[3] W. J. Broadgate, P. S. Liss, and S. A. Penkett, "Seasonal emissions of isoprene and other reactive hydrocarbon gases from the ocean," Geophysical Research Letters, vol. 24, no. 21, pp. 2675-2678, 1997. 
[4] A. Ekberg, A. Arneth, H. Hakola, S. Hayward, and T. Holst, "Isoprene emission from wetland sedges," Biogeosciences, vol. 6, no. 4, pp. 601-613, 2009.

[5] G. P. Ayers, R. W. Gillett, H. Granek, C. De Serves, and R. A. Cox, "Formaldehyde production in clean marine air," Geophysical Research Letters, vol. 24, no. 4, pp. 401-404, 1997.

[6] N. Carslaw, D. J. Creasey, D. E. Heard, et al., "Modeling OH, $\mathrm{HO}_{2}$, and $\mathrm{RO}_{2}$ radicals in the marine boundary layer 1. Model construction and comparison with field measurements," Journal of Geophysical Research Atmospheres, vol. 104, no. D23, pp. 30241-30255, 1999.

[7] A. C. Lewis, K. D. Bartle, D. E. Heard, J. B. McQuaid, M. J. Pilling, and P. W. Seakins, "In situ, gas chromatographic measurements of non-methane hydrocarbons and dimethyl sulfide at a remote coastal location (Mace Head, Eire) July-August 1996," Journal of the Chemical Society, Faraday Transactions, vol. 93, no. 16, pp. 2921-2927, 1997.

[8] A. C. Lewis, L. J. Carpenter, and M. J. Pilling, "Nonmethane hydrocarbons in Southern Ocean boundary layer air," Journal of Geophysical Research Atmospheres, vol. 106, no. D5, pp. 4987-4994, 2001.

[9] E. Liakakou, M. Vrekoussis, B. Bonsang, Ch. Donousis, M. Kanakidou, and N. Mihalopoulos, "Isoprene above the Eastern Mediterranean: seasonal variation and contribution to the oxidation capacity of the atmosphere," Atmospheric Environment, vol. 41, no. 5, pp. 1002-1010, 2007.

[10] M. Claeys, B. Graham, G. Vas et al., "Formation of secondary organic aerosols through photooxidation of isoprene," Science, vol. 303, no. 5661, pp. 1173-1176, 2004.

[11] J. H. Kroll and J. H. Seinfeld, "Chemistry of secondary organic aerosol: formation and evolution of low-volatility organics in the atmosphere," Atmospheric Environment, vol. 42, no. 16, pp. 3593-3624, 2008.

[12] S. Platnick and S. Twomey, "Determining the susceptibility of cloud albedo to changes in droplet concentration with the advanced very high resolution radiometer," Journal of Applied Meteorology, vol. 33, no. 5, pp. 334-347, 1994.

[13] P. G. Falkowski, Y. Kim, Z. Kolber, C. Wilson, C. Wirick, and R. Cess, "Natural versus anthropogenic factors affecting lowlevel cloud albedo over the North Atlantic," Science, vol. 256, no. 5061, pp. 1311-1313, 1992.

[14] R. Boers, G. P. Ayers, and J. L. Gras, "Coherence between seasonal variation in satellite-derived cloud optical depth and boundary layer CCN concentrations at a mid- latitude Southern Hemisphere station," Tellus, Series B, vol. 46, no. 2, pp. 123-131, 1994.

[15] R. Boers, J. R. Acarreta, and J. L. Gras, "Satellite monitoring of the first indirect aerosol effect: retrieval of the droplet concentration of water clouds," Journal of Geophysical Research Atmospheres, vol. 111, no. 22, Article ID D22208, 2006.

[16] S. M. Vallina, R. Simó, and S. Gassó, "What controls CCN seasonality in the Southern Ocean? A statistical analysis based on satellite-derived chlorophyll and CCN and modelestimated $\mathrm{OH}$ radical and rainfall," Global Biogeochemical Cycles, vol. 20, no. 1, Article ID GB1014, 2006.

[17] N. Meskhidze and A. Nenes, "Phytoplankton and cloudiness in the Southern Ocean," Science, vol. 314, no. 5804, pp. 1419 1423, 2006.

[18] Y. Hu, M. Vaughan, C. McClain et al., "Global statistics of liquid water content and effective number concentration of water clouds over ocean derived from combined CALIPSO and MODIS measurements," Atmospheric Chemistry and Physics, vol. 7, no. 12, pp. 3353-3359, 2007.
[19] C. Hoose, J. E. Kristjánsson, T. Iversen, A. Kirkevåg, Ø. Seland, and A. Gettelman, "Constraining cloud droplet number concentration in GCMs suppresses the aerosol indirect effect," Geophysical Research Letters, vol. 36, no. 12, Article ID L12807, 2009.

[20] W. J. Broadgate, G. Malin, F. C. Küpper, A. Thompson, and P. S. Liss, "Isoprene and other non-methane hydrocarbons from seaweeds: a source of reactive hydrocarbons to the atmosphere," Marine Chemistry, vol. 88, no. 1-2, pp. 61-73, 2004.

[21] S. L. Shaw, S. W. Chisholm, and R. G. Prinn, "Isoprene production by Prochlorococcus, a marine cyanobacterium, and other phytoplankton," Marine Chemistry, vol. 80, no. 4, pp. 227-245, 2003.

[22] B. Gantt, N. Meskhidze, and D. Kamykowski, "A new physically-based quantification of marine isoprene and primary organic aerosol emissions," Atmospheric Chemistry and Physics, vol. 9, pp. 4915-4927, 2009.

[23] O. W. Wingenter, K. B. Haase, P. Strutton et al., "Changing concentrations of $\mathrm{CO}, \mathrm{CH}_{4}, \mathrm{C}_{5} \mathrm{H}_{8}, \mathrm{CH}_{3} \mathrm{Br}, \mathrm{CH}_{3} \mathrm{I}$, and dimethyl sulfide during the Southern Ocean Iron Enrichment Experiments," Proceedings of the National Academy of Sciences of the United States of America, vol. 101, no. 23, pp. 8537-8541, 2004.

[24] R. M. Moore and L. Wang, "The influence of iron fertilization on the fluxes of methyl halides and isoprene from ocean to atmosphere in the SERIES experiment," Deep-Sea Research, vol. 53, no. 20-22, pp. 2398-2409, 2006.

[25] P. J. Milne, D. D. Riemer, R. G. Zika, and L. E. Brand, "Measurement of vertical distribution of isoprene in surface seawater, its chemical fate, and its emission from several phytoplankton monocultures," Marine Chemistry, vol. 48, no. 3-4, pp. 237-244, 1995.

[26] A. R. Baker, S. M. Turner, W. J. Broadgate et al., "Distribution and sea-air fluxes of biogenic trace gases in the eastern Atlantic Ocean," Global Biogeochemical Cycles, vol. 14, no. 3, pp. 871$886,2000$.

[27] S. Matsunaga, M. Mochida, T. Saito, and K. Kawamura, "In situ measurement of isoprene in the marine air and surface seawater from the western North Pacific," Atmospheric Environment, vol. 36, no. 39-40, pp. 6051-6057, 2002.

[28] L. Acuna-Alvarez, D. A. Exton, K. N. Timmis, D. J. Suggett, and T. J. McGenity, "Characterization of marine isoprenedegrading communities," Environmental Microbiology, vol. 11, no. 12 , pp. 3280-3291, 2009.

[29] D. J. Erickson III and J. L. Hernandez, "A global, high resolution, satellite-based model of air-sea isoprene flux," in Gas Transfer at Water Surfaces, vol. 127 of Geophysical Monograph, American Geophysical Union, 2002.

[30] N. Meskhidze and A. Nenes, "Reply to comment on "Phytoplankton and cloudiness in the Southern Ocean"', Science, vol. 317, no. 5834, pp. 42-43, 2007.

[31] O. W. Wingenter, "Isoprene, cloud droplets, and phytoplankton," Science, vol. 317, no. 5834, pp. 42-43, 2007.

[32] M. Ratte, O. Bujok, A. Spitzy, and J. Rudolph, "Photochemical alkene formation in seawater from dissolved organic carbon: results from laboratory experiments," Journal of Geophysical Research Atmospheres, vol. 103, no. D5, pp. 5707-5717, 1998.

[33] R. M. Moore, D. E. Oram, and S. A. Penkett, "Production of isoprene by marine phytoplankton cultures," Geophysical Research Letters, vol. 21, no. 23, pp. 2507-2510, 1994.

[34] A. Colomb, N. Yassaa, J. Williams, I. Peeken, and K. Lochte, "Screening volatile organic compounds (VOCs) emissions from five marine phytoplankton species by head space gas chromatography/mass spectrometry (HS-GC/MS)," Journal of Environmental Monitoring, vol. 10, no. 3, pp. 325-330, 2008. 
[35] N. Yassaa, I. Peeken, E. Zöllner et al., "Evidence for marine production of monoterpenes," Environmental Chemistry, vol. 5, no. 6, pp. 391-401, 2008.

[36] W. A. McKay, M. F. Turner, B. M. R. Jones, and C. M. Halliwell, "Emissions of hydrocarbons from marine phytoplanktonsome results from controlled laboratory experiments," Atmospheric Environment, vol. 30, no. 14, pp. 2583-2593, 1996.

[37] S. R. Arnold, D. V. Spracklen, J. Williams, et al., "Evaluation of the global oceanic isoprene source and its impacts on marine organic carbon aerosol," Atmospheric Chemistry and Physics, vol. 9, pp. 1253-1262, 2009.

[38] T. Evans and J. E. Mak, "Biological Volatile Organic Compounds (BVOCs) emissions from the planktonic diatom Thalassiosira pseudonana," in Proceedings of the American Geophysical Union, Fall Meeting, 2009, abstract no. A11B0089.

[39] V. Sinha, J. Williams, M. Meyerhöfer, U. Riebesell, A. I. Paulino, and A. Larsen, "Air-sea fluxes of methanol, acetone, acetaldehyde, isoprene and DMS from a Norwegian fjord following a phytoplankton bloom in a mesocosm experiment," Atmospheric Chemistry and Physics, vol. 7, no. 3, pp. 739-755, 2007.

[40] B. Gantt, N. Meskhidze, Y. Zhang, and J. Xu, "The effect of marine isoprene emissions on secondary organic aerosol and ozone formation in the coastal United States," Atmospheric Environment, vol. 44, no. 1, pp. 115-121, 2010.

[41] P. I. Palmer and S. L. Shaw, "Quantifying global marine isoprene fluxes using MODIS chlorophyll observations," Geophysical Research Letters, vol. 32, no. 9, Article ID L09805, 5 pages, 2005.

[42] G. Luo and F. Yu, "A numerical evaluation of global oceanic emissions of $\alpha$-pinene and isoprene," Atmospheric Chemistry and Physics, vol. 10, no. 4, pp. 2007-2015, 2010.

[43] A. B. Guenther, R. K. Monson, and R. Fall, "Isoprene and monoterpene emission rate variability: observations with eucalyptus and emission rate algorithm development," Journal of Geophysical Research Atmospheres, vol. 96, no. D6, pp. 10799-10808, 1991.

[44] N. Gist and A. C. Lewis, "Seasonal variations of dissolved alkenes in coastal waters," Marine Chemistry, vol. 100, no. 12, pp. 1-10, 2006.

[45] S. Haapanala, J. Rinne, K.-H. Pystynen, H. Hellén, H. Hakola, and T. Riutta, "Measurements of hydrocarbon emissions from a boreal fen using the REA technique," Biogeosciences, vol. 3, no. 1, pp. 103-112, 2006.

[46] H. Hellén, H. Hakola, K.-H. Pystynen, J. Rinne, and S. Haapanala, "C2-C10 hydrocarbon emissions from a boreal wetland and forest floor," Biogeosciences, vol. 3, no. 2, pp. 167174, 2006.

[47] P. Tiiva, R. Rinnan, T. Holopainen, S. K. Mörsky, and J. K. Holopainen, "Isoprene emissions from boreal peatland microcosms; effects of elevated ozone concentration in an open field experiment," Atmospheric Environment, vol. 41, no. 18, pp. 3819-3828, 2007.

[48] S. Fares, F. Brilli, I. Noguès et al., "Isoprene emission and primary metabolism in Phragmites australis grown under different phosphorus levels," Plant Biology, vol. 10, no. 1, pp. 38-43, 2008.

[49] H. K. Lichtenthaler, "The 1-deoxy-D-xylulose-5-phosphate pathway of isoprenoid biosynthesis in plants," Annual Review of Plant Physiology and Plant Molecular Biology, vol. 50, pp. 47-65, 1999.
[50] A. C. Lewis, J. B. McQuaid, N. Carslaw, and M. J. Pilling, "Diurnal cycles of short-lived tropospheric alkenes at a north Atlantic coastal site," Atmospheric Environment, vol. 33, no. 15, pp. 2417-2422, 1999.

[51] J. P. Greenberg, A. B. Guenther, and A. Turnipseed, "Marine organic halide and isoprene emissions near Mace Head, Ireland," Environmental Chemistry, vol. 2, no. 4, pp. 291-294, 2005.

[52] I. E. Galbally, S. J. Lawson, I. A. Weeks et al., "Volatile organic compounds in marine air at Cape Grim, Australia," Environmental Chemistry, vol. 4, no. 3, pp. 178-182, 2007.

[53] Y. Yokouchi, H.-J. Li, T. Machida, S. Aoki, and H. Akimoto, "Isoprene in the marine boundary layer (Southeast Asian Sea, eastern Indian Ocean, and Southern Ocean): comparison with dimethyl sulfide and bromoform," Journal of Geophysical Research Atmospheres, vol. 104, no. D7, pp. 8067-8076, 1999.

[54] A. Colomb, V. Gros, S. Alvain et al., "Variation of atmospheric volatile organic compounds over the Southern Indian Ocean (30-49 S)," Environmental Chemistry, vol. 6, no. 1, pp. 70-82, 2009.

[55] B. Gantt, N. Meskhidze, and A. G. Carlton, "The impact of marine organics on the air quality of the western United States," Atmospheric Chemistry and Physics Discussions, vol. 10, no. 3, pp. 6257-6278, 2010.

[56] M. E. Hay and W. Fenical, "Marine plant-herbivore interactions: the ecology of chemical defense," Annual Review of Ecology and Systematics, vol. 19, pp. 111-145, 1988.

[57] M. L. Wise, "Monoterpene biosynthesis in marine algae," Phycologia, vol. 42, no. 4, pp. 370-377, 2003.

[58] J. H. Sartin, C. J. Halsall, B. Davison, S. Owen, and C. N. Hewitt, "Determination of biogenic volatile organic compounds (C8-C16) in the coastal atmosphere at Mace Head, Ireland," Analytica Chimica Acta, vol. 428, no. 1, pp. 61-72, 2001.

[59] C. Wiedinmyer, A. Guenther, P. Harley, et al., "Global organic emissions from vegetation," in Emissions of Atmospheric Trace Compounds, C. Granier, P. Artaxo, and C. E. Reeves, Eds., Kluwer Academic Publishers, Dordrecht, The Netherlands, 2004.

[60] D. K. Button, "Evidence for a terpene-based food chain in the Gulf of Alaska," Applied and Environmental Microbiology, vol. 48, no. 5, pp. 1004-1011, 1984.

[61] A. Guenther, C. N. Hewitt, D. Erickson, et al., "A global model of natural volatile organic compound emissions," Journal of Geophysical Research Atmospheres, vol. 100, no. D5, pp. 88738892, 1995.

[62] S. Alvain, C. Moulin, Y. Dandonneau, and F. M. Bréon, "Remote sensing of phytoplankton groups in case 1 waters from global SeaWiFS imagery," Deep-Sea Research Part I, vol. 52, no. 11, pp. 1989-2004, 2005.

[63] D. Kamykowski, S.-J. Zentara, J. M. Morrison, and A. C. Switzer, "Dynamic global patterns of nitrate, phosphate, silicate, and iron availability and phytoplankton community composition from remote sensing data," Global Biogeochemical Cycles, vol. 16, no. 4, Article ID 1077, 2002.

[64] D. V. Spracklen, S. R. Arnold, J. Sciare, K. S. Carslaw, and C. Pio, "Globally significant oceanic source of organic carbon aerosol," Geophysical Research Letters, vol. 35, no. 12, Article ID L12811, 2008.

[65] G. J. Roelofs, "A GCM study of organic matter in marine aerosol and its potential contribution to cloud drop activation," Atmospheric Chemistry and Physics, vol. 8, no. 3, pp. 709-719, 2008. 
[66] J. R. Hopkins, I. D. Jones, A. C. Lewis, J. B. McQuaid, and P. W. Seakins, "Non-methane hydrocarbons in the Arctic boundary layer," Atmospheric Environment, vol. 36, no. 20, pp. 32173229, 2002.

[67] D. E. Heard, K. A. Read, J. Methven et al., "The North Atlantic Marine Boundary Layer Experiment (NAMBLEX). Overview of the campaign held at Mace Head, Ireland, in summer 2002," Atmospheric Chemistry and Physics, vol. 6, no. 8, pp. 22412272, 2006.

[68] B. Langmann, C. Scannell, and C. O’Dowd, "New directions: organic matter contribution to marine aerosols and cloud condensation nuclei," Atmospheric Environment, vol. 42, no. 33, pp. 7821-7822, 2008.

[69] P. Vaattovaara, P. E. Huttunen, Y. J. Yoon et al., "The composition of nucleation and Aitken modes particles during coastal nucleation events: evidence for marine secondary organic contribution," Atmospheric Chemistry and Physics, vol. 6, no. 12, pp. 4601-4616, 2006.

[70] R. L. Modini, Z. D. Ristovski, G. R. Johnson et al., "New particle formation and growth at a remote, sub-tropical coastal location," Atmospheric Chemistry and Physics, vol. 9, no. 19, pp. 7607-7621, 2009.

[71] M. Claeys, W. Wang, R. Vermeylen et al., "Chemical characterisation of marine aerosol at Amsterdam Island during the austral summer of 2006-2007," Journal of Aerosol Science, vol. 41, no. 1, pp. 13-22, 2010. 

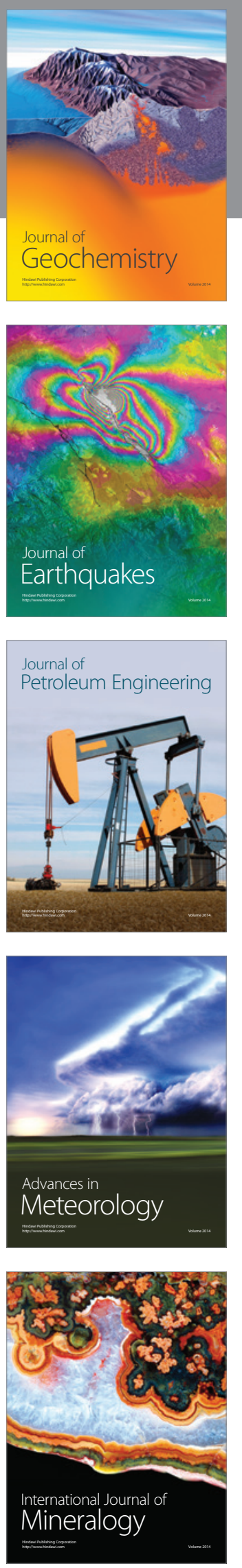
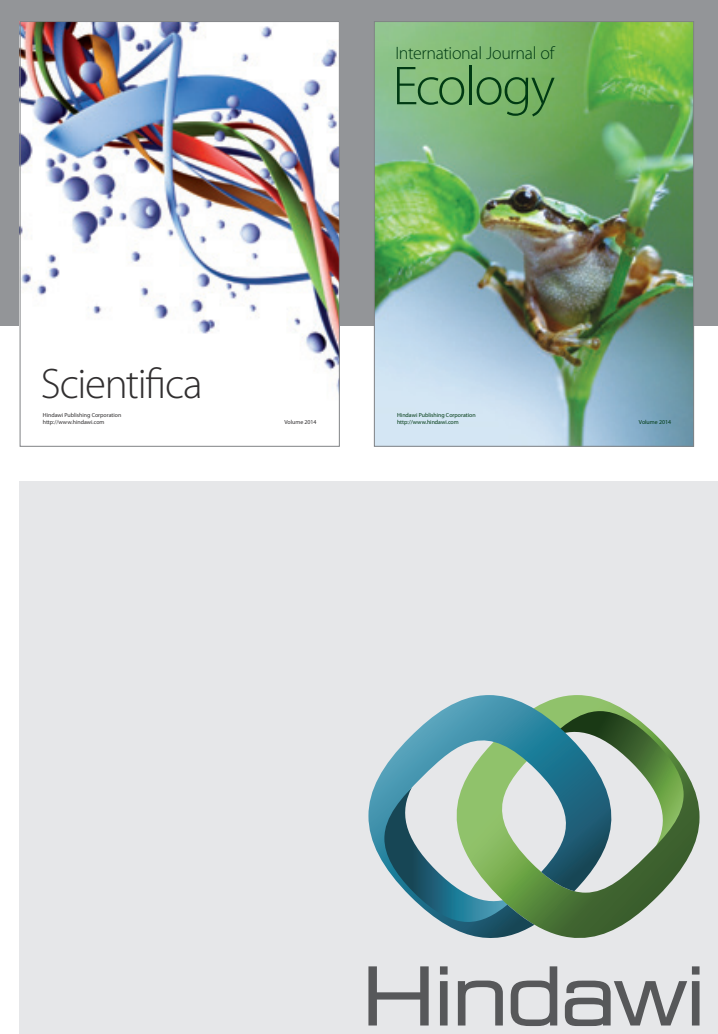

Submit your manuscripts at http://www.hindawi.com
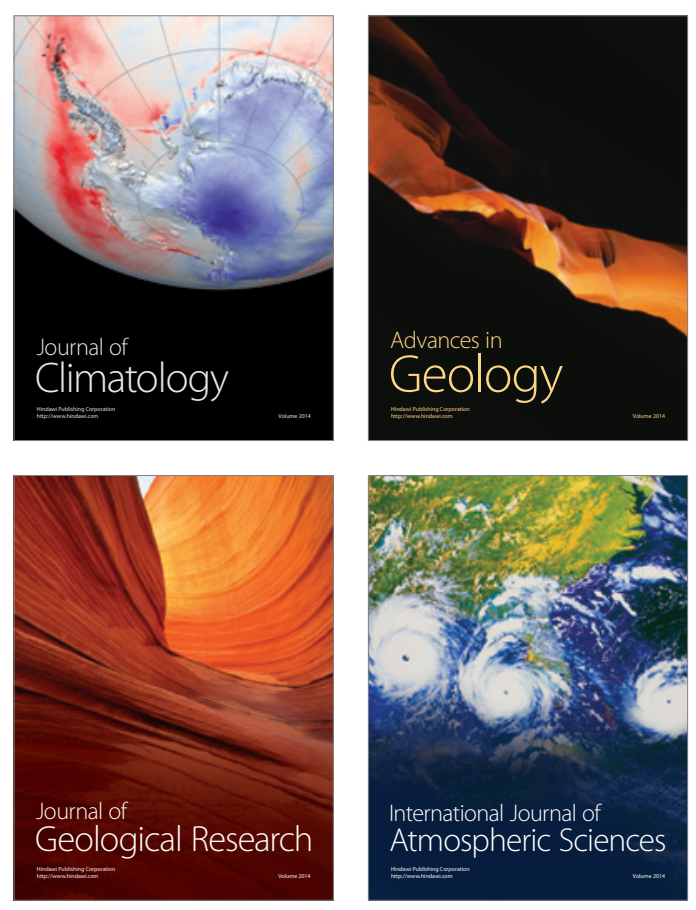
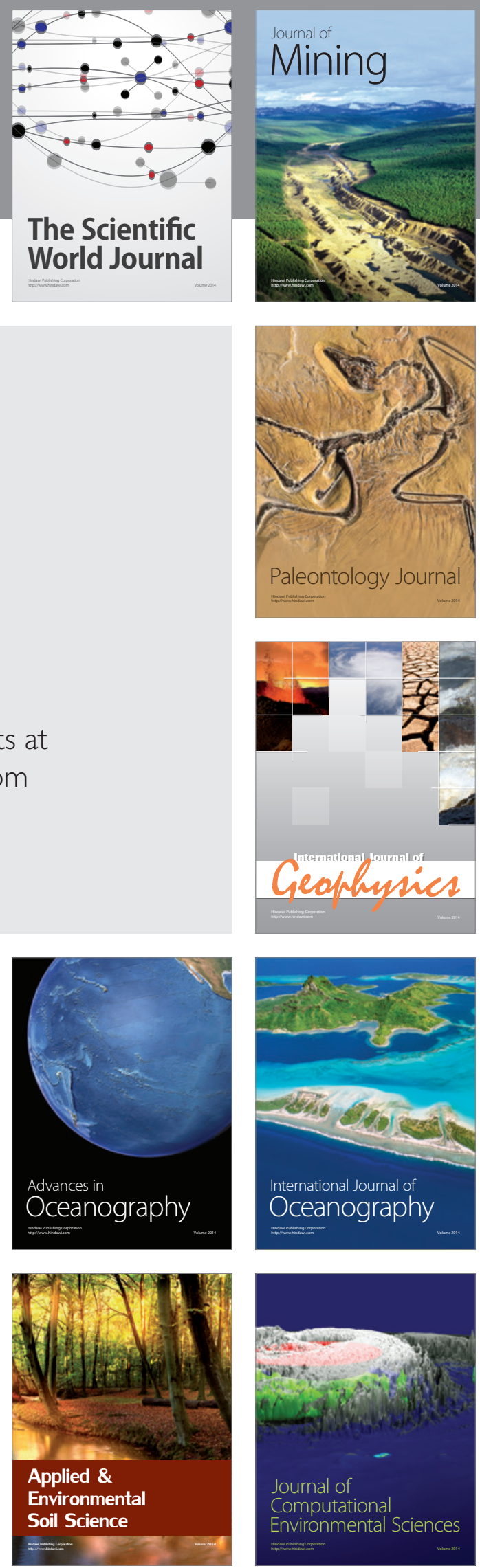